\title{
Comparative genomics and physiological investigation supported safety, cold adaptation, efficient hydrolytic and plant growth-promoting potential of psychrotrophic Glutamicibacter arilaitensis LJH19, isolated from night-soil compost
}

\author{
Shruti Sinai Borker ${ }^{1,2}$, Aman Thakur ${ }^{1,2}$, Sanjeet Kumar ${ }^{1}$, Sareeka Kumari ${ }^{1}$, Rakshak Kumar ${ }^{1 *}$ and Sanjay Kumar ${ }^{1}$
}

\begin{abstract}
Background: Night-soil compost (NSC) has traditionally been conserving water and a source of organic manure in northwestern Himalaya. Lately, this traditional method is declining due to modernization, its unhygienic conditions, and social apprehensions. Reduction in the age-old traditional practice has led to excessive chemical fertilizers and water shortage in the eco-sensitive region. In the current study, a bacterium has been analyzed for its safety, coldadaptation, efficient degradation, and plant growth-promoting (PGP) attributes for its possible application as a safe bioinoculant in psychrotrophic bacterial consortia for improved night-soil composting.

Results: Glutamicibacter arilaitensis LJH19, a psychrotrophic bacterium, was isolated from the NSC of Lahaul valley in northwestern Himalaya. The strain exhibited amylase $(186.76 \pm 19.28 \mathrm{U} / \mathrm{mg})$, cellulase $(21.85 \pm 0.7 \mathrm{U} / \mathrm{mg})$, and xylanase $(11.31 \pm 0.51 \mathrm{U} / \mathrm{mg})$ activities at $10^{\circ} \mathrm{C}$. Possessing efficient hydrolytic activities at low-temperature garners the capability of efficient composting to LJH19. Additionally, the strain possessed multiple PGP traits such as indole acetic acid production $(166.11 \pm 5.7 \mu \mathrm{g} / \mathrm{ml})$, siderophore production $(85.72 \pm 1.06 \% \mathrm{psu})$, and phosphate solubilization (44.76 \pm $1.5 \mathrm{\mu g} / \mathrm{ml}$ ). Enhanced germination index and germination rate of pea seeds under the LJH19 inoculation further supported the bacterium's PGP potential. Whole-genome sequencing $(3,602,821 \mathrm{bps})$ and genome mining endorsed the cold adaptation, degradation of polysaccharides, and PGP traits of LJH19. Biosynthetic gene clusters for type III polyketide synthase (PKS), terpene, and siderophore supplemented the endorsement of LJH19 as a potential PGP bacterium. Comparative genomics within the genus revealed 217 unique genes specific to hydrolytic and PGP activity. Conclusion: The physiological and genomic evidence promotes LJH19 as a potentially safe bio-inoculant to formulate psychrotrophic bacterial consortia for accelerated degradation and improved night-soil compost.
\end{abstract}

Keywords: Winter dry toilet, Polysaccharide metabolism, Indole acetic acid, siderophore, type III PKS

\footnotetext{
*Correspondence: rakshak@ihbt.res.in; rakshakacharya@gmail.com

'Biotechnology Division, CSIR-Institute of Himalayan Bioresource Technology Palampur, Palampur, Himachal Pradesh 176061, India

Full list of author information is available at the end of the article
}

(c) The Author(s). 2021, corrected publication 2021. Open Access This article is licensed under a Creative Commons Attribution 4.0 International License, which permits use, sharing, adaptation, distribution and reproduction in any medium or format, as long as you give appropriate credit to the original author(s) and the source, provide a link to the Creative Commons licence, and indicate if changes were made. The images or other third party material in this article are included in the article's Creative Commons licence, unless indicated otherwise in a credit line to the material. If material is not included in the article's Creative Commons licence and your intended use is not permitted by statutory regulation or exceeds the permitted use, you will need to obtain permission directly from the copyright holder. To view a copy of this licence, visit http://creativecommons.org/ licenses/by/4.0/. The Creative Commons Public Domain Dedication waiver (http://creativecommons.org/publicdomain/zero/1. 0/) applies to the data made available in this article, unless otherwise stated in a credit line to the data. 


\section{Background}

The highland agro system of the northwestern Himalaya lacks productivity and soil fertility due to extreme weather conditions like heavy snowfall, avalanches, landslides, soil erosion, and scanty rainfall [1]. To meet the high demand for manure and water shortage during winter, the traditional method of composting human excreta (night-soil) using dry toilets is prevalent in this region [2-4]. The dry toilet consists of a defaecation room (upper storey) and a collection chamber (lower storey) (Fig. 1a). After the defaecation, the feces is covered with ' $f \circ t^{\prime}$ composed of dry mixtures of dry cattle/sheep dung, kitchen ash, sand, dry grass/leaves, etc. (Fig. 1b). The night-soil is decomposed with time and dumped into the open fields in a series of piles for further curing (Fig. 1c). Lately, the night-soil composting practice is declining, promoting excessive chemical fertilizers use in ecologically vulnerable high altitude farmlands [3]. Promotion of the safe and hygienic winter dry toilets aided with scientific intervention is necessary to sustain the agro-ecosystem and conservation of water in such highland areas.

The foul odor of the winter dry toilet has been one of the main reasons for the decline of this practice. In a cold climate, the lower microbial load in the initial composting process delays the composting process due to slower biomass degradation, and psychrotrophic bacteria play a crucial role in low-temperature composting [5].
Plant growth-promoting (PGP) bacteria play an important role in maintaining soil fertility by increasing the availability of the nutrients, such as iron, nitrogen, phosphorous, and by producing phytohormones (indole acetic acid- IAA), growth regulators (siderophores), and solubilizing phosphate to modulate plant growth and development [6, 7]. In isolating the psychrotrophic, efficiently degrading strains with PGP potential to formulate psychrotrophic bacterial consortium for application in night-soil composting, we obtained a bacterial strain LJH19 with remarkable PGP traits and efficient hydrolytic activity in in-vitro assays. Owing to its cold adaptation, efficient hydrolytic activity, PGP potential, and origin from fecal compost, whole-genome sequencing was performed to elucidate the genetic basis of the catabolic activities, PGP traits, and analysis for pathogenicity determinants.

Further, to explore the habitat-specific gene repertoire, we performed comparative genomics of LJH19 with all the available strains of the same genus. A comparison was withdrawn with the closely related strains based on a unique genome region across the strain LJH19. Biosynthetic gene clusters in the genome of LJH19 were also identified, and further to evaluate bacterial safety, the presence of antibiotic resistance gene cluster across all the strains was assessed. It is important to study each potential bacterium individually to formulate an efficient psychrotrophic bacterial
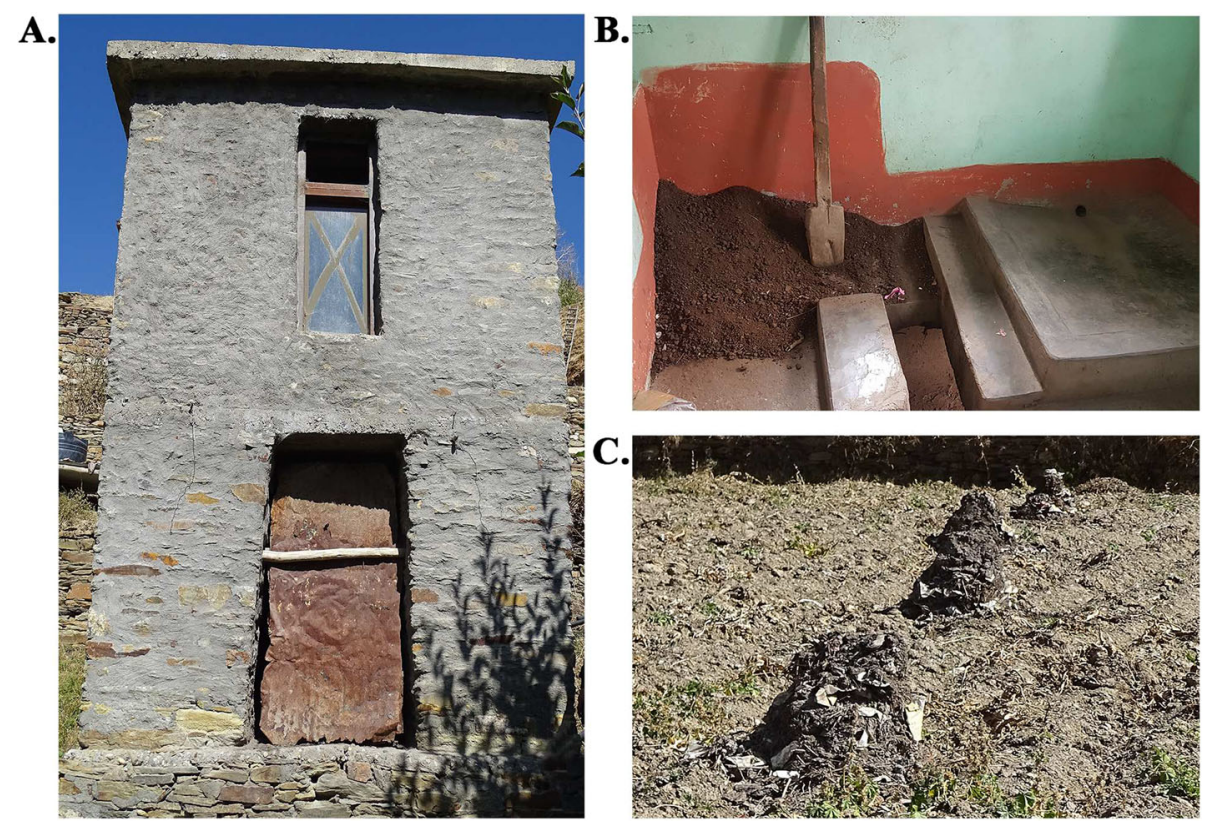

Fig. 1 Traditional winter dry toilet of Lahaul valley. a Traditional winter dry toilet attached to the living room of the main house. The dry toilet structure is made up of two-storey construction, i.e., defaecation room and collection chamber. $\mathbf{b}$ Inside view of the defaecation room. After defaecation, the night-soil is thoroughly covered with mixture locally referred as 'fot' (composed of dry cattle/sheep dung, kitchen ash, and dry grass/leaves). c NSC pile dumped in open fields for further curing 
consortium. The current study aims to establish strain LJH19 as a potential bio-inoculant for application in consortia for night-soil composting.

\section{Results and discussion}

Physico-chemical properties of night-soil compost (NSC) samples and bacterial characterization

The compost samples were collected from the compost pile randomly in triplicate from the collection chamber of the traditional dry toilet 'ghop' (Fig. 1a). The compost sample was obtained from the core of the pile; the temperature, $\mathrm{pH}$, and electrical conductivity $(\mathrm{EC})$ of the collected samples were $9.9^{\circ} \mathrm{C}, 10$, and $1674 \mu \mathrm{S}$, respectively. The available nitrogen, phosphorous, and potassium in the collected NSC samples were $2297.6 \pm 99.4$ $\mathrm{ppm}, \quad 117.11 \pm 0.34 \mathrm{ppm}$, and $22,534.11 \pm 73.08 \mathrm{ppm}$, respectively.

In an attempt to explore the bacterial diversity from NSC, 130 bacterial strains belonging to varied taxonomic genera were obtained based on their hydrolytic activities in different substrates and PGP traits (unpublished data). One such efficient hydrolytic bacterial colony was an opaque, yellow-pigmented bacterium LJH19 that showed multiple hydrolytic activities. The bacterium could survive at varying temperatures $\left(4-37^{\circ} \mathrm{C}\right)$ and showed optimum growth at $10^{\circ} \mathrm{C}, \mathrm{pH} 7$ (Table 1). The bacterium showed hydrolytic activity against substrates like corn starch, CMC, and birchwood xylan on plate-based assays at a varied temperature of $4-37^{\circ} \mathrm{C}$, and the most efficient activity was obtained at $10^{\circ} \mathrm{C}$ (Table 1, Supplementary Figure S1). Gene sequence similarity based on partial 16S rRNA gene (NCBI accession no. MT349443) related the bacteria to G. arilaitensis $\operatorname{Re} 117^{\mathrm{T}}$ with $100 \%$ identity and coverage of $96.5 \%$ in EzTaxon Biocloud (https://www.ezbiocloud.net/identify). Quantitatively, LJH19 showed enzyme activity at varying temperatures $(4,10,15$, 20,28 , and $37^{\circ} \mathrm{C}$ ), and the best production was obtained at $10^{\circ} \mathrm{C}$. At $10^{\circ} \mathrm{C}$, the strain $\mathrm{LJH} 19$ exhibited production of amylase enzyme with a specific activity of $186.76 \pm 19.28 \mathrm{U} /$ mg (Supplementary Figure S2) using corn starch as substrate, cellulase enzyme with a specific activity of $21.85 \pm 0.7$ $\mathrm{U} / \mathrm{mg}$ (Supplementary Figure S2) using CMC as a substrate and xylanase enzyme with a specific activity of $11.31 \pm 0.51$ $\mathrm{U} / \mathrm{mg}$ (Supplementary Figure S2) using birchwood xylan as a substrate. It has been hypothesized that psychrotrophic bacteria play a crucial role in low-temperature composting, and it is critical for a bacterium to possess enzymatic activities to ensure efficient composting [5, 8, 9]. Like LJH19, other strains of genus Glutamicibacter have also been reported to possess hydrolytic enzymes such as amylase and cellulase [10,11]. Glutamicibacter strains have been reported from varied niche areas [12], and its reclassification originates from a much diverse genera Arthrobacter [13]. Genus Arthrobacter has also been reported from a harsh
Table 1 Physiological characterization, hydrolytic, plant growth promoting, and pathogenic attributes of G. arilaitensis LJH19

\begin{tabular}{|c|c|}
\hline Characteristic & G. arilaitensis LJH19 \\
\hline Source & Night-soil compost \\
\hline \multicolumn{2}{|l|}{ Growth condition $^{a}$} \\
\hline Temperature range & $4-37^{\circ} \mathrm{C}\left(10^{\circ} \mathrm{C}\right)$ \\
\hline $\mathrm{pH}$ range & $7-11(7)$ \\
\hline $\mathrm{NaCl}$ range & $1-9 \%(1 \%)$ \\
\hline \multicolumn{2}{|l|}{ Hydrolysis on agar plates ${ }^{b}$} \\
\hline Corn starch & + ve $(15)$ \\
\hline Carboxymethylcellulose (CMC) & + ve $(5.66)$ \\
\hline Birchwood xylan & + ve $(2.8)$ \\
\hline Tributyrin & + ve $(1.8)$ \\
\hline \multicolumn{2}{|l|}{ Enzyme assays } \\
\hline Amylase & $186.76 \pm 19.28 \mathrm{U} / \mathrm{mg}$ \\
\hline Cellulase & $21.85 \pm 0.7 \mathrm{U} / \mathrm{mg}$ \\
\hline Xylanase & $11.31 \pm 0.51 \mathrm{U} / \mathrm{mg}$ \\
\hline \multicolumn{2}{|l|}{ PGP trait } \\
\hline IAA production & $166.11 \pm 5.7 \mu \mathrm{g} / \mathrm{ml}$ \\
\hline Siderophore production ${ }^{c}$ & $85.72 \pm 1.06 \%$ siderophore unit (1.5) \\
\hline Phosphate solubilisation $^{d}$ & $44.76 \pm 1.5 \mu \mathrm{g} / \mathrm{ml}(2.3)$ \\
\hline Ammonia production & $0.20 \pm 0.01 \mu \mathrm{moles} / \mathrm{ml}$ \\
\hline Germination Index (GI) & $116.348 \pm 38.02 \%$ \\
\hline \multicolumn{2}{|l|}{ Pathogenic potential } \\
\hline Haemolysis on blood agar & - ve \\
\hline Protease production & $0.17 \pm 0.002 \mathrm{U} / \mathrm{mg}$ \\
\hline Biofilm production & - ve at $37^{\circ} \mathrm{C}$, weak producer at $15^{\circ} \mathrm{C}$ \\
\hline Antibiotic susceptibility test & $\begin{array}{l}A Z M^{-}, \mathrm{AMP}^{-}, \mathrm{CIP}^{-}, \mathrm{CHL}^{-}, \mathrm{E}^{-}, \mathrm{G}^{-}, \mathrm{K}^{-} \\
\mathrm{P}^{-}, \mathrm{RIF}^{-}, \mathrm{S}^{-}, \mathrm{TE}^{-}, \mathrm{VA}^{-}\end{array}$ \\
\hline
\end{tabular}

Values in parentheses indicate aptimum growth condition, ${ }^{\mathrm{b}}$ enzymatic index at $10^{\circ} \mathrm{C}$, ${ }^{c}$ Siderophore producing index; ${ }^{d}$ phosphate solubilization index; + : Resistant; -: Sensitive; AZM: 15 mcg, Azithromycin; AMP: 10 mcg, Ampicillin; CIP: $5 \mathrm{mcg}$, Ciprofloxacin; CHL: $30 \mathrm{mcg}$, Chloramphenicol; E: $15 \mathrm{mcg}$ Erythromycin; G:10 mcg, Gentamycin; K: 30 mcg, Kanamycin; P: 10 Units, Penicillin-G; RIF: $5 \mathrm{mcg}$, Rifampicin; S: $10 \mathrm{mcg}$, Streptomycin; TE: $30 \mathrm{mcg}$, Tetracycline; VA: $30 \mathrm{mcg}$, Vancomycin

cold environment with potential hydrolytic enzymes [14, 15]. With survival at a temperature as low as $4{ }^{\circ} \mathrm{C}$ and efficient hydrolytic activity against complex polysaccharides (starch, cellulose, and xylan), the strain LJH19 was chosen as a potential candidate for psychrotrophic consortia for accelerated degradation of NSC at low ambient temperature.

The nutrients released after the decomposition of polysaccharides tend to leave the agricultural systems due to leaching, surface runoff, and eutrophication [16]. As a result, availability for plant uptake is always questionable; however, the inhabitant PGP bacteria improves nutrient uptake and produces phytohormones aiding the efficiency of applied compost [17]. Hence, $\mathrm{LJH} 19$ was further explored to investigate its PGP potential for additional properties to become a suitable 
bioinoculant candidate forenhancing soil nutrients at high altitude agro-ecosystems. In the qualitative assay for siderophore production, the LJH19 strain showed orange halo zones at varying temperatures and the best results of the siderophore index of 1.5 at $10{ }^{\circ} \mathrm{C}$ (Table 1) (Supplementary Figure S3D). Quantitatively, LJH19 exhibited considerable siderophore production of $85.72 \pm$ $1.06 \%$ siderophore unit (psu) at $10{ }^{\circ} \mathrm{C}$. In the absorption spectra, we observed a peak at $292 \mathrm{~nm}$ supporting the presence of 2,3-dihydroxybenzoic acid (DHB) in the supernatant (Supplementary Figure S4). A previous study reported that in acidic medium DHB, a phenolic compound consisting of a catechol group absorbs below $330 \mathrm{~nm}$ showing two absorption bands with maxima at $254 \mathrm{~nm}$ and $292 \mathrm{~nm}$, respectively [18]. DHB is an intermediate involved in the synthesis of catecholate type siderophore [19]. This evidence supports the presence of DHB in the supernatant, indicating the production of catecholate type siderophore by strain LJH19. Siderophore production by PGPB is vital for plant defense. Iron chelation by siderophores suppresses fungal pathogens in the rhizosphere [20]. LJH19 also demonstrated the ability to produce $166.11 \pm 5.7 \mu \mathrm{g} / \mathrm{ml}$ of IAA after $72 \mathrm{Hrs}$ of incubation with $200 \mu \mathrm{g} / \mathrm{ml}$ concentration of L-Trytophan at $10^{\circ} \mathrm{C}$ (Supplementary Figure S3A), signifying that auxin production occurs through the tryptophan-dependent pathway. Production of phytohormone IAA is essential for plant growth to proliferate lateral roots and root hairs [21]. Qualitative estimation of phosphate solubilization by LJH19 showed positive results at varying temperatures, and the best activity of 2.3 solubilization index was displayed at $10^{\circ} \mathrm{C}$ (Table 1$)$. Quantitatively, LJH19 solubilized $44.76 \pm 1.5 \mu \mathrm{g} / \mathrm{ml}$ of tricalcium phosphate at $10^{\circ} \mathrm{C}$ after the 5 th day of incubation in NBRIP broth (Supplementary Figure S3C). The activity of bacteria decreased $\mathrm{pH}$ from 7 to 4.5 , indicating the elevation of phosphate solubilization levels. Thus the results suggested, the presence of LJH19 in the compost can deliver available phosphorous to the plants. Since plants cannot uptake inorganic phosphate present in a fixed or precipitated form in the soil, bacteria aids in increasing the availability of soluble $\mathrm{P}$ for plant acquisition through solubilization [22]. While performing in-vitro assays for ammonia production, strain $\mathrm{LJH} 19$ produced a low level of ammonia $(0.20 \pm 0.01 \mu \mathrm{moles} / \mathrm{ml})$ (Supplementary Figure S3B) after 10 days of incubation in peptone water. Ammonia production by bacteria is yet another PGP feature to increase nitrogen availability [23]. However, these values are relatively low in the case of PGP attributes. In the composting case, ammonia gas released by bacteria is primarily responsible for the pungent smell and loss of organic nitrogen from the compost [24]. The results may therefore suggest that it doesn't directly benefit the plants but may maintain stable organic nitrogen content in the compost by not converting rich nitrogenous sources into ammonia gas.

The seed germination rate was significantly higher in the treated pea Pisum sativum var. Arkel seeds $(83.33 \pm$ $15.27 \%)$ from the control (66.66 $\pm 15.27 \%)$ (Supplementary Figure S5). The relative seed germination, relative root growth, and relative shoot growth were noticeably increased to $135.55 \pm 33.55 \%, 103.70 \pm 33.60 \%$, and $112.78 \pm 12.14 \%$ respectively, subjected to the treatment of pea seeds with bacterial inoculation. The germination index was further recorded as $116.348 \pm 38.02 \%$ under the bacterial influence. The LJH19 strain capabilities to produce auxin and siderophore may have positively affected pea seeds' seed germination. In agreement with our findings, other Glutamicibacter strains have also shown PGP traits where a strain G. halophytocola KLMP 1580 have significantly promoted the growth of Limonium sinense under high salinity stress [25]. In another study, G. halophytocola KLMP 1580 was also reported to enhance tomato seedlings' growth [26]. Another Glutamicibacter species, G. creatinolyticus was reported as an efficient PGPR with IAA production [27]. Similarly, the closest related genus Arthrobacter has also been reported to exhibit excellent PGP attributes, having a potential role in recovering burned soils of holm-oak forests $[15,28,29]$.

Owing to the source of LJH19 strain isolation from night-soil, it was mandatory to ensure its safety for humans before declaring it as a suitable candidate as a bioinoculant. Hence, the strain LJH19 was tested for its pathogenicity. In general, any pathogenic bacteria rely on various virulence factors to induce pathogenesis, including adhesion proteins, toxins like hemolysins, and proteases [30]. The initial screening of virulence of LJH19 performed on blood agar showed no hemolytic activity compared to the other tested hemolytic strains MTCC 96, MTCC121, MTCC 43, MTCC 2470 (Supplementary Figure S6A). LJH19 was tested positive for protease activity with an enzymatic index of 12.5 (Supplementary Figure S6B), but, quantitatively LJH19 showed very low protease activity (Table 1 ).

Furthermore, strain LJH19 was not observed to form biofilm on polystyrene at $37^{\circ} \mathrm{C}$ (Supplementary Figure $\mathrm{S} 6 \mathrm{C})$. The adherence of bacteria to the host tissue cells is the initial step to induce the pathogenesis [31]. Therefore, biofilm formation is a notable virulence factor of pathogenic potential and is directly related to the strain's safety. The LJH19 strain also exhibited antibiotic susceptibility to all the 12 antibiotics tested (Supplementary Figure S6D), (Table 1).

Night-soil composting remains dormant during winters as the temperature goes to sub-zero conditions, and microbial degradation plays an insignificant role in odor formation. However, in the summer months, where the 
temperature ranges from 5 to $25^{\circ} \mathrm{C}$ [1], slow microbial metabolism due to low microbial load produces a strong odor during composting. During this period, night-soil composting can be improved by supplementing it with a psychrotrophic bacterial consortium. Owing to the survivability at $4{ }^{\circ} \mathrm{C}$ and efficient hydrolytic activity at varying temperatures (best activity at $10^{\circ} \mathrm{C}$ ), nonpathogenicity, and PGP potential, strain LJH 19 qualifies a potential bio-inoculant candidate for the preparation of a psychrotrophic consortium for accelerated degradation and quality improvement of NSC. Further, the whole genome sequencing, data mining, and comparative genomics of strain LJH19 bacterium were explored to obtain genetic bases on its potential to be a safe bio-inoculant for the consortia and to investigate the niche-specific gene repertoire.

\section{Genomic features of strain LJH19}

RS hierarchical genome assembly was performed as described previously in Kumar et al. [32]. The assembly generated a draft genome (4 contigs) of 3,602,821 bp (N50 read length 2,610,692) with 59.60\% GC content with average mean coverage of $153 \mathrm{X}$ (Supplementary Table S1) (GenBank accession number: SPDS00000000). The NCBI Prokaryotic Genome Annotation Pipeline (URL: www.ncbi.nlm.nih.gov/genome/annotation_prok) prediction revealed a total of 3517 genes out of which 3396 were protein-coding genes (covering $96.56 \%$ of the genome) and 99 RNA genes ( 30 rRNAs, 66 tRNAs, and 03 other RNA genes). There was no plasmid DNA in the genome of LJH19, as evident by no observation of bands in agarose gel electrophoresis after the plasmid isolation. Additionally, in silico analysis with PLSDB web-based tool supported no plasmid existence in the genome of LJH19.

\section{Whole genome-based phylogenetic assessment and genome relatedness}

Figure The 16S rRNA gene phylogenetic tree clustered the strains G. arilaitensis LJH19, G. arilaitensis JB182, and type strain G. arilaitensis $\operatorname{Re} 117^{\mathrm{T}}$ into a single clade (Fig. 2a). The phylogenetic analysis using PhyloPhlAn pipeline with 400 conserved gene sequences of Glutamicibacter sp. was also congruent in clustering the strains G. arilaitensis LJH19, JB182, and type strain $\mathrm{Re} 117^{\mathrm{T}}$ into a single clade (Fig. 2b). The average nucleotide identity (ANI) between genomes was calculated using orthoANI to differentiate species at a $95 \%$ similarity threshold. The ANI matrix also suggests the genome similarity of the strain LJH19 to G. arilaitensis Re117 ${ }^{\mathrm{T}}$ and JB182 (Fig. 2c).

\section{Pan-genome analysis and chromosomal map}

Roary run for the strains forming a clade with the type strains of G. arilaitensis and LJH19 resulted in a pan- genome of 9892 genes. A total of 634 genes were found to be core genes, whereas the gene clusters specific to the strain $\mathrm{LJH} 19, \mathrm{Re} 117^{\mathrm{T}}$, and BJ182 were 1740 . A total of 217 genes were specific to the strain LJH19. Chromosomal map showing the unique genomic regions across the strain LJH19 depicts the uniqueness of the strain LJH19 (Fig. 3a). All the strain-specific gene from LJH19 classified by eggNOG falls in several clusters of orthologous groups (COG) categories (Fig. $3 \mathrm{~b}$ ). A list of the unique gene, function, and COG classification is reported in Supplementary Table S2. Based on the annotation and unique genes data, an image illustrating a schematic representation of predicted genes associated with catabolic activities, transport, and plant growth promotion of the genome of LJH19 was generated (Fig. 4).

\section{Genomic insights into the safety of LJH19}

Virulence is a characteristic of pathogenicity which confers the ability to initiate and sustain infection for the organism. The occurrence of such determinants at the genetic level makes the organism potentially pathogenic with the ability to circulate such genes in the bacterial population [33]. The LJH19 genome was analyzed for the presence of virulence factors using the virulence factors of the pathogenic bacteria database (VFDB) [34]. We found LJH19 contained few genes designated as virulence factors (Supplementary Table S3). Putative chain-fatty acid-CoA ligase (FadD13) is required for maintenance of the appropriate mycolic acid composition and envelope permeability in Mycobacterium sp. and is involved in the fatty acid biosynthesis pathway, a portion of lipid metabolism [35]. We found 12 hits for FadD13 gene in LJH19 genome. To further confirm these results, the LJH19 genome was assessed for its pathogenic potential by PathogenFinder [36]. The web-based tool identifies the genome and provides a probability measure for the test strain to be pathogenic for humans. The predicted results identified LJH19 as a non-human pathogen with an average probability of 0.356 (Supplementary Table S4). None of the putative virulence or pathogenic genes were identified in the tested genome. The LJH19 genome was further screened for the antibiotic resistance genes using CARD pipeline [37]. Evaluation of resistomes in the genome revealed 208 hits to drug classes (Supplementary Table S5). The AMR gene family identified were beta-lactamase, glycopeptide resistance gene cluster, trimethoprim resistant dihydrofolate reductase, tetracycline-resistant ribosomal protection protein, sulfonamide resistant, rifampin phosphotransferase, resistance-nodulation-cell division (RND) antibiotic efflux pump major facilitator superfamily (MFS), antibiotic efflux pump, resistance-nodulation-cell division (RND) antibiotic efflux pump, etc. (Supplementary Table S5). These results indicated resistance against drugs such as tetracycline, rifamycin, quinolones, macrolactams, 
A.

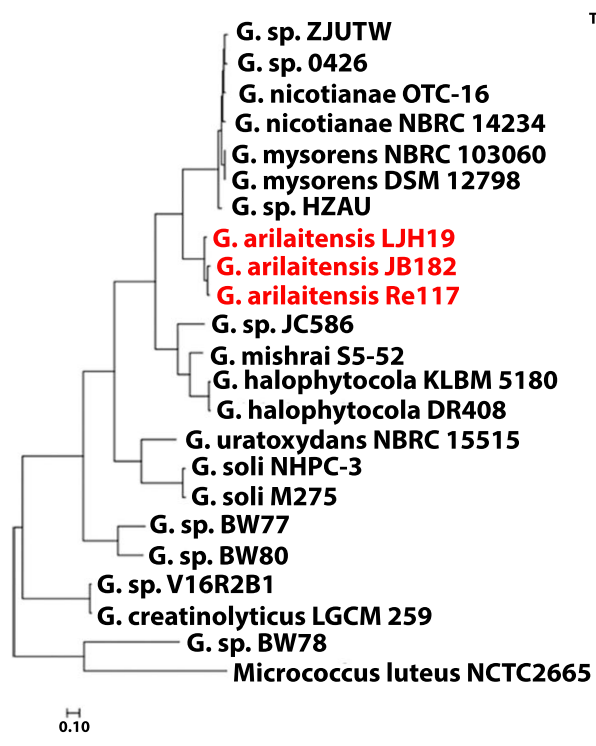

B.

Tree scale: $0.1-$

c.
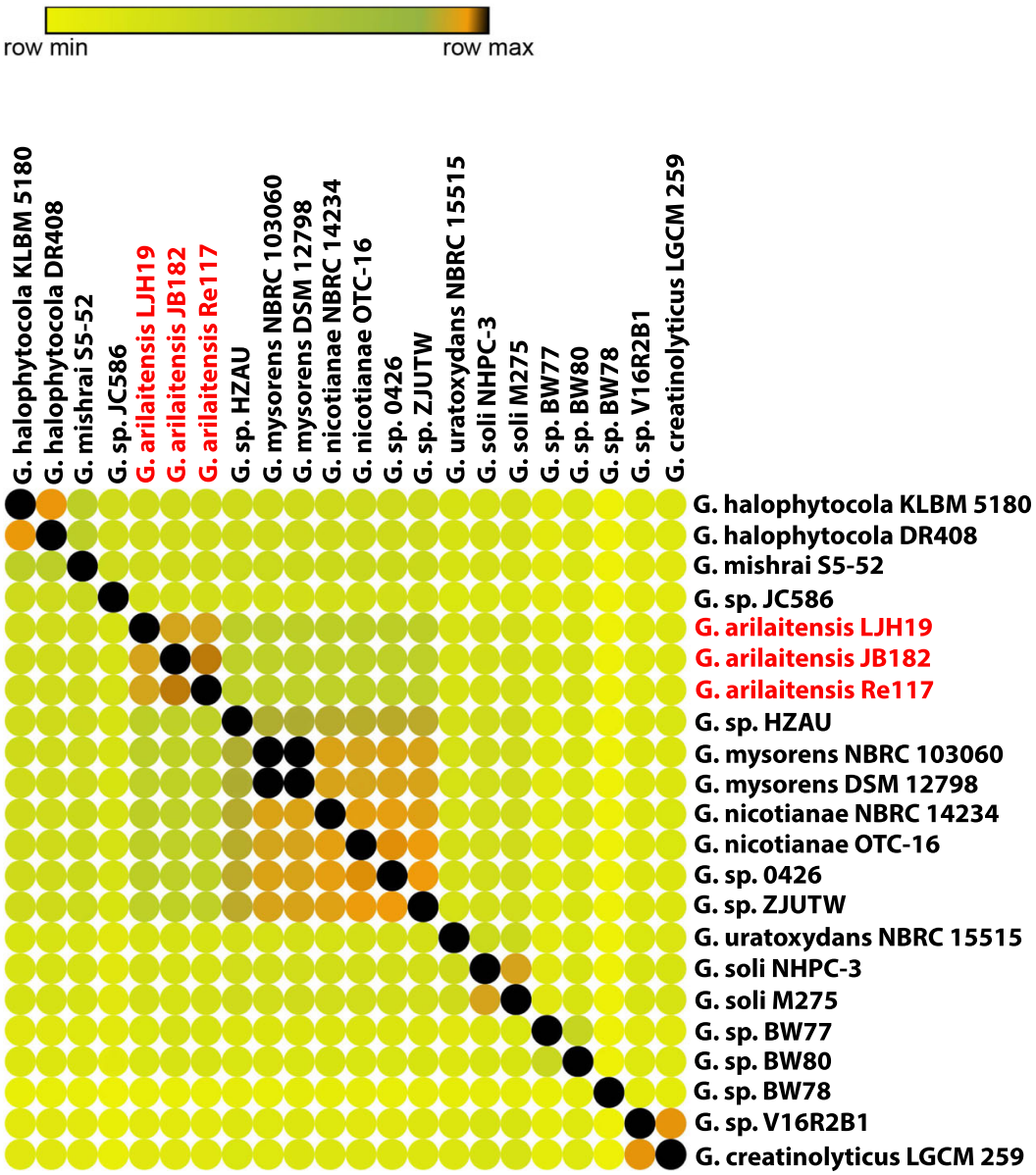

Fig. 2 (See legend on next page.) 
(See figure on previous page.)

Fig. 2 Phylo-taxono-genomics of Glutamicibacter arilaitensis LJH19. a 16S rRNA gene phylogeny obtained from all available Glutamicibacter strains. b ML-based phylogenomic tree construction obtained from the whole proteome information of the strains of genus Glutamicibacter. Violet color circle at each node represents corresponding bootstrap values. c OrthoANI similarity matrix created with morpheous, red color represents the maximum values, yellow color represents the minimum values, green color is the intermediate values, and orange color represents the cutoff value for species demarcation ( $95 \%$ similarity)

macrolides, aminoglycoside, lincosamide, carbapenem, cephalosporin, pyrazinamide, etc. (Supplementary Table S5). However, LJH19 displayed a negative resistance phenotype to all the 12 antibiotics tested in the in vitro assays (Table 1; Figure S6D). These results suggested the safety of strain LJH19.

\section{Genomic insights into the cold adaptation of LJH19}

Psychrotrophic bacteria isolated from high altitude ecosystems have unique adaptations to survive in a cold environment maintaining their growth and metabolism [32]. LJH19 was isolated from a night-soil compost of the high-altitude ecosystem of Lahaul valley in northwestern Himalaya that experiences extreme temperature variations [1]. Psychrotrophic bacteria sustain these extreme factors with unique cold-adapted proteins active at low temperatures. There are reports on such coldassociated genes in the genome of cold-adapted bacteria $[9,32,38]$. LJH19 genome also predicted several cold- associated genes encoding for proteins responsible for cold-active chaperons, general stress, osmotic stress, oxidative stress, membrane/cell wall alteration, carbon storage/ starvation, DNA repair, Toxin/Antitoxin modules were identified across the genome (Table 2). This genomic evidence supports the versatility of the LJH19 strain to survive in a broad temperature range of 4 to $37^{\circ} \mathrm{C}$. Bacteria inhabiting high altitude regions are also prone to the accumulation of reactive oxygen species (ROS) such as hydrogen peroxide, superoxide's, and hydroxyl radicals, and to prevent the damage caused by these radical bacteria synthesize antioxidative enzymes [9, 32, 38, 39]. Similarly, the LJH19 genome predicted multiple genes encoding antioxidant enzymes such as catalase, superoxide dismutase, thioredoxin, and Thioredoxin-disulphide reductase (Table 2). Additionally, the genome of the strain LJH19 also predicted genes encoding proteins involved in DNA repairs such as Recombinase, DNA repair protein RadA, DNA

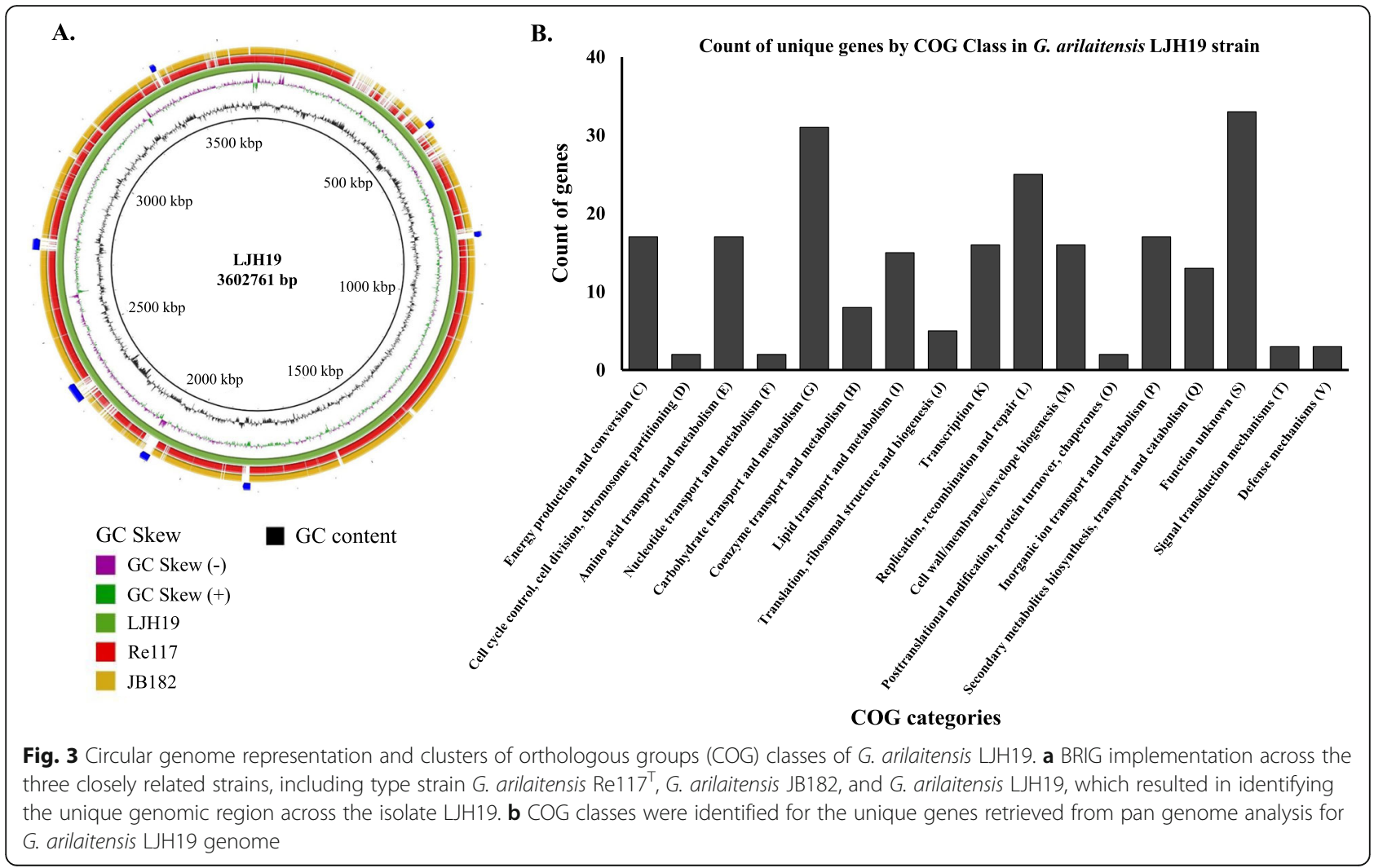




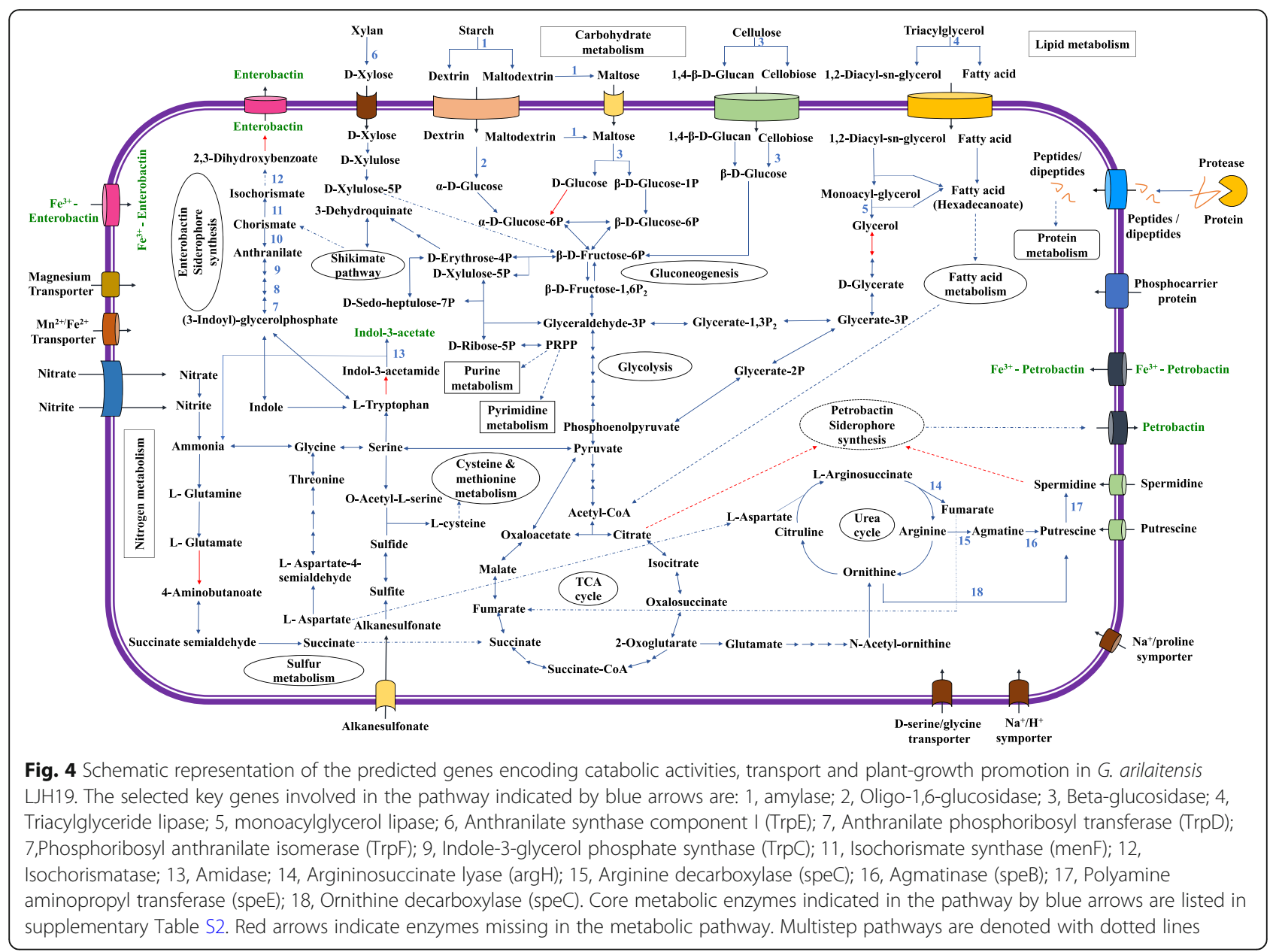

integrity scanning protein DisA, and DNA repair protein $\operatorname{RecN}$ (Table 2) that may aid in the robust feature of strain LJH19 in surviving the extreme conditions.

Genomic insights on nutritional versatility and adaptation to environmental stresses have been documented previously for other Glutamicibacter strains [12]. Similar to genomic evidence on cold adaptation of LJH19, adaptation towards salt tolerance, oxidative and osmotic stress tolerance from varied ecological habitats such as cheese, coastal halophyte, rhizospheric soil, and coral Favia veroni have been reported previously (Supplementary Table S6) [26, 40-42]. Likewise, multiple reports on genomic evidence to support physiological adaptation for varied stress adaptations in the nearest genus Arthrobacter are also available [14, 15, 29, 43] (Supplementary Table S6). The current study and other genomic insights supported the niche-specific adaptational strategies of the genus Glutamicibacter in the varied ecological habitats.

\section{Genomic insights into the hydrolytic potential of LJH19}

The biodegradation of complex polysaccharide molecules by bacteria requires a cocktail of enzymes to depolymerize it to oligosaccharides and monomer sugars
[44]. The genome of LJH19 showed the occurrence of multi copies of genes encoding for proteins responsible for the metabolism of a wide variety of complex polysaccharides like cellulose, starch, and xylan. Similar to the finding in LJH19, the genome of G. arilaitensis $\operatorname{Re} 117^{\mathrm{T}}$ strain also has been reported encoding genes involved in protein and lipid degradation [41] (Supplementary Table S6). The key enzymes encoded in the LJH19 genome are beta-glucosidase, alpha-amylase, beta-xylosidase, pullulanase, oligo-1,6-glucosidase, and glycosidases associated with the degradation of polysaccharides (Fig. 4; Table 3; Supplementary Table S5). These findings endorse the experimental evidence of LJH19 showing enzymatic activities against complex polysaccharides that aids in the improved composting process. For the utilization of cellulosic substrates, psychrotrophic bacteria requires the $\mathrm{ABC}$ transporters specific for the hydrolytic product, such as cellobiose, cellodextrin, $\beta$-D-Glucose. Cellulases such as beta-glucosidase cleave the $\beta$-(1,4)-glycosidic linkages within the cellulose polymer releasing cellobiose, glucose, and cellodextrin, which are then transported inside the cell via specific transporters [45]. LJH19 genome also predicted genes encoding proteins that are 
Table 2 Genes encoding known cold \& stress response and DNA repair proteins as predicted in the genome of G. arilaitensis LJH19

Category and GenBank ID
Cold active chaperones
TFH54768, TFH56297, TFH57075
TFH56633
TFH56634, TFH54762
TFH57159
TFH54768, TFH56297, TFH57075
TFH56633
TFH56416
TFH56424
TFH57532

Carbon storage/starvation

TFH54400

TFH56944, TFH57627, TFH57801

Membrane/cell wall alteration

TFH55154

TFH57491

TFH57492

\section{General Stress response}

TFH55892, TFH56176, TFH56200, TFH56262, TFH57611, TFH55142, TFH54651, TFH55629

TFH57700, TFH57339

TFH54980, TFH56483

TFH57322

TFH54953

TFH57081

\section{Toxin/Antitoxin modules}

TFH54837

TFH54532

TFH54610

TFH56658

\section{Description}

Cold-shock protein

Co-chaperone GroES

Chaperonin GroEL

Molecular chaperone DnaJ

Cold-shock protein

Co-chaperone GroES

Molecular chaperone DnaK

ATP-dependent chaperone ClpB

Heat shock protein HsIJ / META

domain-containing protein

Molecular chaperone DnaK

ATP-dependent chaperone ClpB

Carbon starvation protein A

1-acyl-sn-glycerol-3-phosphate acyltransferase

3-oxoacyl-ACP synthase III

Phytoene desaturase

Phytoene/squalene synthase

Universal stress protein

GlsB/YeaQ/YmgE family stress response membrane protein

Serine/threonine protein kinase

Peroxide stress protein YaaA

$50 S$ ribosomal protein $L 25$

SOS response-associated peptidase

Type II toxin-antitoxin system prevent-host-death family antitoxin

Type II toxin-antitoxin system VapB TFH55568 family antitoxin

Type II toxin-antitoxin system HipA TFH57664 family toxin

Type II toxin-antitoxin system Phd/ TFH57433 YefM family antitoxin

\section{TFH55567}

\section{Category and GenBank ID Description}

Osmotic Stress/ Oxidative stress

TFH56153

TFH56253

TFH56254

TFH56255

TFH56256

TFH56949

TFH57402, TFH54880

TFH56696, TFH56988,

TFH56162

TFH55537

TFH55668, TFH56321, TFH56523, TFH54754, TFH55543

TFH55669

TFH55955, TFH57498

TFH56887

TFH54908

TFH56279

TFH54956

TFH54753

TFH54752

\section{DNA repair}

TFH54856, TFH54452

TFH55191

TFH57358

TFH57661

TFH57734

TFH54405

TFH57167
Glycine betaine ABC transporter substrate-binding protein

Sarcosine oxidase subunit beta family protein

Sarcosine oxidase subunit delta family protein

Sarcosine oxidase subunit alpha family protein

Sarcosine oxidase subunit gamma family protein

Superoxide dismutase

Catalase

OsmC family peroxiredoxin

Organic hydroperoxide resistance protein

Thioredoxin

Thioredoxin-disulfide reductase

Thioredoxin-dependent thiol peroxidase

Thioredoxin family protein

Thioredoxin domain-containing protein

Sodium/proline symporter PutP $\mathrm{Na}^{+} / \mathrm{H}^{+}$antiporter NhaA

Trehalose-6-phosphate synthase

Trehalose-phosphatase

Recombinase family protein

Recombinase RecA

Tyrosine recombinase XerC

Site-specific tyrosine recombinase XerD

Recombinase

ATP-dependent DNA helicase RecQ

DNA repair protein RadA

DNA repair protein $\mathrm{RecO}$

DNA integrity scanning protein DisA

DNA repair protein RecN

ATP-dependent DNA helicase RecG 
Table 2 Genes encoding known cold \& stress response and DNA repair proteins as predicted in the genome of G. arilaitensis LJH19 (Continued)

\begin{tabular}{llll}
\hline Category and GenBank ID & Description & Category and GenBank ID & Description \\
\hline TFH57154 & $\begin{array}{l}\text { Type II toxin-antitoxin system } \\
\text { PemK/MazF family toxin }\end{array}$ & TFH56747 & $\begin{array}{l}\text { ATP-dependent DNA helicase } \\
\text { UvrD2 }\end{array}$ \\
TFH57340 & $\begin{array}{l}\text { Toxin component of a toxin/ } \\
\text { antitoxin system } \\
\text { Serine/threonine-protein kinase }\end{array}$ & TFH57103 junction branch \\
TFH55640 & TFH57104 & $\begin{array}{l}\text { Holliday junction branch } \\
\text { migration DNA helicase RuvB } \\
\end{array}$ \\
& & TFH57121 & Holliday junction resolvase \\
& & RuvX \\
\hline
\end{tabular}

components of transporter complexes engaged in the recognition and transport of monosaccharides and oligosaccharides such as maltose/maltodextrin, maltooligosaccharide, and cellobiose and transporters for hydrolyzed proteins (Table 3; Supplementary Table S6).

Furthermore, genes such as triacylglycerol lipase were also predicted associated with fatty acid degradation (Fig. 4; Supplementary Table S6). Within the cells, enzymes (like beta-glucosidase, oligo-1,6-glucosidase, alpha-amylase) attack the polysaccharides producing smaller oligosaccharides and monomeric sugars. Finally, the monomeric sugars like glucose go into the glycolysis pathway and ultimately to the TCA cycle generating energy for cellular growth [46]. For better understanding, an overview of a similar mechanism has been represented in the LJH19 cell based on the prediction of genes encoding critical proteins for polysaccharides metabolism and transporters from the genome (Fig. 4).

\section{Genomic insights into plant growth-promoting potential of LJH 19}

A series of genes encoding enzymes related to PGP traits predicted in the LJH19 genome were amidase, isochorismate synthase, isochorismatase family protein YecD, nitrite reductase, nitrate reductase, and alkaline phosphatase (Table 3). Quantitatively LJH19 strain showed auxin production by utilizing L-tryptophan, and it got endorsed by the genomic evidence that predicted tryptophan dependent pathway utilizing L-tryptophan (Fig. 4; Table $3)$. Genes encoding amidase, $\mathrm{N}$-acetyltransferase, and acetaldehyde dehydrogenase for auxin synthesis were predicted in the LJH19 genome (Table 3; Fig. 4). Auxin plays a vital role in the development of lateral plant roots and stem elongation [21]. The experimental studies also have shown remarkable siderophore production by LJH19 strain that is an important plant defense, suppressing fungal pathogens in the rhizosphere [20]. Upon genome mining, genes involved in the synthesis of polyamines (PAs), putrescine (Put), and spermidine (Spd) were also identified in the LJH19 genome (Table 3; Supplementary Table S6). In bacteria, these active molecules are involved in siderophore biosynthesis, improve the survival rate in freezing conditions, and stabilize spheroplasts and protoplasts from osmotic shock [47].

As discussed earlier, experimental evidence suggested that LJH19 is involved in the catecholate type siderophore production. The genomic insights further strengthened these findings by predicting the genes involved in enterobactin and petrobactin's biosynthesis (Table 3). These results indicate that $\mathrm{LJH} 19$ has the potential to produce a wide variety of siderophores. Most of the enzymes involved in enterobactin biosynthesis were predicted except the genes involved in converting 2,3-Dihydro-2,3-dihydroxybenzoate to enterobactin, marked as a red arrow in Fig. 4 (Supplementary Table S2). LJH19 genome also predicted the genes encoding the transporters required for the import and export of synthesized enterobactin. In respect to petrobactin's biosynthesis, spermidine molecules are used for synthesis using citrate backbone [48].

Further, genes encoding the transporters required to import and export both synthesized enterobactin and petrobactin and transporters for hydroxamate type siderophores were predicted in the genome (Supplementary Tables S2, S6). In addition to auxin and siderophore, the LJH19 genome also predicted few genes encoding phosphatases, inositol-phosphatases, and gluconate permease (Fig. 4; Table 2; Supplementary Table S6) involved in phosphate metabolism. LJH19 strain has also been noted to carry genes involved in nitrate/nitrite transport pathways, including the genes associated with denitrification and nitrate reduction like nitrite reductase and nitrate reductase (Fig. 4; Table 3; Supplementary Table S6). Nitrite reductase encoded by the NirD gene converts nitrite to ammonium and further converted to glutamate by glutamate synthetase for amino acid metabolism (Fig. 4). Thus, LJH19 may deliver plants with available nitrogen sources via enzymatic conversion.

The cold-tolerant LJH19 has shown potential PGP properties physiologically, and genomic evidence has supported the function. Similar genomic insights for saline tolerant strain G. halophytocola KLBMP 5180 has also been reported to carry the genes related to PGP, such as siderophores and spermidine biosynthesis [26]. Like LJH19, KLBMP 5180 also harbored genes such as 
Table 3 Genes encoding proteins involved in catabolic activity, plant growth promoting activity, transport and cold adaptation predicted in the genome of G. arilaitensis LJH19

\begin{tabular}{|c|c|c|c|}
\hline Category and GenBank ID & Description & $\begin{array}{l}\text { Category and } \\
\text { GenBank ID }\end{array}$ & Description \\
\hline Catabolic activity & & \multicolumn{2}{|c|}{ Plant Growth Promoting activity } \\
\hline TFH56992, TFH56993 & $\begin{array}{l}\text { ATP-dependent Clp protease proteolytic } \\
\text { subunit }\end{array}$ & TFH55608, TFH57060 & amidase \\
\hline TFH56994 & $\begin{array}{l}\text { ATP-dependent Clp protease ATP-binding } \\
\text { subunit ClpX }\end{array}$ & TFH56909 & Anthranilate synthase component I \\
\hline TFH54429 & Putative esterase & TFH56082 & Nitrite reductase $[\mathrm{NAD}(\mathrm{P}) \mathrm{H}]$ \\
\hline TFH56413 & pullulanase-type alpha-1,6-glucosidase & TFH56083 & $\begin{array}{l}\text { nitrite reductase }(N A D(P) H) \text { small } \\
\text { subunit }\end{array}$ \\
\hline TFH57366 & trypsin-like serine protease & TFH56086 & nitrite reductase \\
\hline TFH56438 & MarP family serine protease & TFH57000 & nitrite/sulfite reductase \\
\hline TFH57809 & Alpha-amylase & TFH55619 & nitrate reductase \\
\hline TFH54465 & alpha/beta fold hydrolase & TFH56511 & Isochorismate synthase \\
\hline TFH54414 & Beta-glucosidase & TFH57125 & chorismate synthase \\
\hline TFH54614 & Xylose isomerase & TFH57182 & Anthranilate phosphoribosyl transferase \\
\hline Transporters & & TFH57559, TFH55965 & Isochorismatase family protein YecD \\
\hline TFH56366 & $\begin{array}{l}\text { spermidine/putrescine } A B C \text { transporter } \\
\text { substrate-binding protein }\end{array}$ & TFH55761 & Acetylornithine aminotransferase \\
\hline $\begin{array}{l}\text { TFH54902, TFH55612, TFH56015, TFH56106, } \\
\text { TFH56479, TFH56632, TFH56864, TFH57051, } \\
\text { TFH57718 }\end{array}$ & amino acid permease & TFH54544 & alkaline phosphatase \\
\hline TFH56389 & $\begin{array}{l}\text { amino acid ABC transporter ATP-binding } \\
\text { protein }\end{array}$ & TFH54792 & Inositol-1-monophosphatase \\
\hline TFH55562 & $\begin{array}{l}\text { phosphate ABC transporter ATP-binding } \\
\text { protein }\end{array}$ & TFH56913 & tryptophan synthase subunit beta \\
\hline TFH55563 & phosphate $\mathrm{ABC}$ transporter permease PstA & TFH56914 & tryptophan synthase subunit alpha \\
\hline TFH55564 & $\begin{array}{l}\text { phosphate } A B C \text { transporter permease } \\
\text { subunit PstC }\end{array}$ & TFH56912 & $\begin{array}{l}\text { indole-3-glycerol phosphate } \\
\text { synthase TrpC }\end{array}$ \\
\hline TFH55565, TFH57701 & $\begin{array}{l}\text { phosphate } A B C \text { transporter substrate-binding } \\
\text { protein PstS }\end{array}$ & TFH55232 & Ornithine carbamoyltransferase \\
\hline TFH55134 & $\begin{array}{l}\text { phosphate/phosphite/phosphonate } A B C \\
\text { transporter substrate-binding protein }\end{array}$ & TFH56276 & ornithine decarboxylase \\
\hline TFH55132 & $\begin{array}{l}\text { phosphonate } A B C \text { transporter, permease } \\
\text { protein PhnE }\end{array}$ & TFH55236 & Argininosuccinate lyase \\
\hline TFH55133 & $\begin{array}{l}\text { phosphonate } A B C \text { transporter ATP-binding } \\
\text { protein }\end{array}$ & TFH55205 & $\begin{array}{l}\text { Phosphoribosyl anthranilate } \\
\text { isomerase PriA }\end{array}$ \\
\hline TFH56773 & $\begin{array}{l}\text { peptide } A B C \text { transporter substrate-binding } \\
\text { protein }\end{array}$ & TFH56212 & Formimidoyl glutamase* (Arginase) \\
\hline TFH54587 & $\begin{array}{l}\text { aliphatic sulfonate } A B C \text { transporter } \\
\text { substrate-binding protein }\end{array}$ & TFH54789 & agmatinase \\
\hline TFH54588 & $A B C$ transporter permease & TFH55596 & inorganic diphosphatase \\
\hline TFH55268 & short-chain fatty acid transporter & TFH56916 & glutamate synthase subunit beta \\
\hline TFH56023 & D-serine/D-alanine/glycine transporter & TFH57767 & glutamate synthase large subunit \\
\hline TFH55620, TFH56087 & MFS transporter (nitrate) & TFH56292 & $\begin{array}{l}\text { FMN-binding glutamate synthase } \\
\text { family protein }\end{array}$ \\
\hline TFH56177 & gluconate permease & TFH56820 & Glutamine synthetase \\
\hline TFH55044 & iron-enterobactin $A B C$ transporter permease & & \\
\hline TFH55045 & $\mathrm{Fe}^{(3+)}$-siderophore $\mathrm{ABC}$ transporter permease & & \\
\hline TFH54561, TFH54802 & siderophore-interacting protein & & \\
\hline TFH54562 & $\begin{array}{l}\mathrm{Fe}^{2+} \text {-enterobactin } \mathrm{ABC} \text { transporter } \\
\text { substrate-binding protein }\end{array}$ & & \\
\hline
\end{tabular}


agmatinase, spermidine synthase, siderophore $A B C$ transport system ATP-binding protein, siderophore ABC transporter substrate-binding protein (Supplementary Table S6). Similarly, G. halophytocola DR408 genome also carried PGP genes involved in siderophore production and phosphate solubilization [42] (Supplementary Table S6). Although few reports of genomic evidence of PGP potential of Glutamicibacter species are available in the literature, the closest related genus Arthrobacter has multiple reports on genetic evidence of PGP traits $[15,29,49,50]$. Among the Arthrobacter species, A. agilis L77 [15] and A. alpinus R3.8 [29] possessing PGP traits such as phosphate solubilization, IAA, and ammonia production are also reported for cold adaptation.

\section{Genomic insights into secondary metabolic gene cluster of LJH19}

Phylum actinobacteria are very well known for producing a variety of secondary metabolites [51]. Secondary metabolites gene clusters search using antiSMASH v5.0 resulted in identifying three biosynthetic gene clusters, namely type III polyketide synthase (PKS), terpene, and siderophore (Fig. 5). Type III PKS are involved in synthesizing numerous metabolites and have various biological and physiological roles, such as antimicrobials and defense systems in bacteria [52]. Such a gene cluster with a probable biological function in producing antimicrobial metabolites favors LJH19 as a PGP bacterium for being a biological control agent against phytopathogens [53]. The presence of a carotenoid gene cluster supports the indicative yellow color of the LJH19 colonies. Besides pigmentation, carotenoid's major function in bacteria is to protect the cell from UV radiations, oxidative damage and modify membrane fluidity [54]. Siderophore production is another attribute that has several ecological applications in plant growth promotion and acts in plant defense against various pathogens [55]. Prediction of the siderophore gene cluster in the genome of LJH19 endorses the experimental evidence of catecholate type siderophore production by LJH19. It supports the presence of several siderophores associated genes in the genome of LJH19.

\section{Conclusion}

Night-soil compost is a rich nutrient source and, when supplemented to the soil, increases its fertility. In this

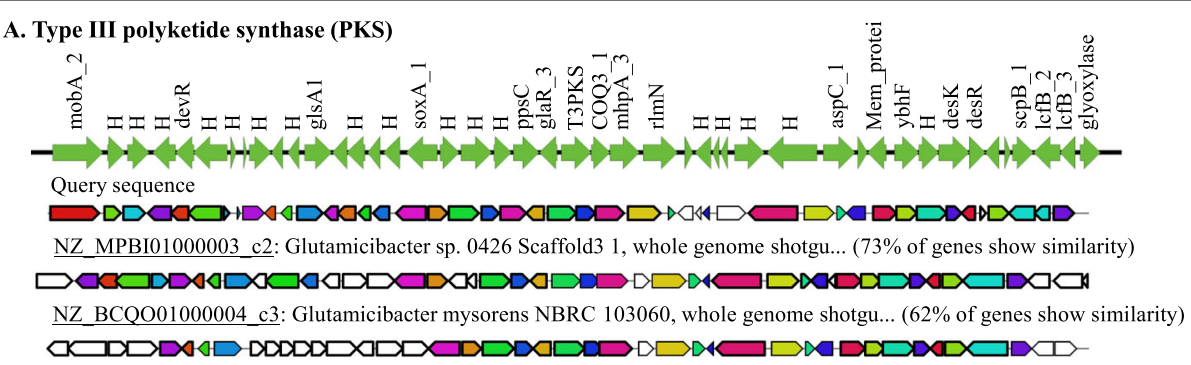

B. Terpene
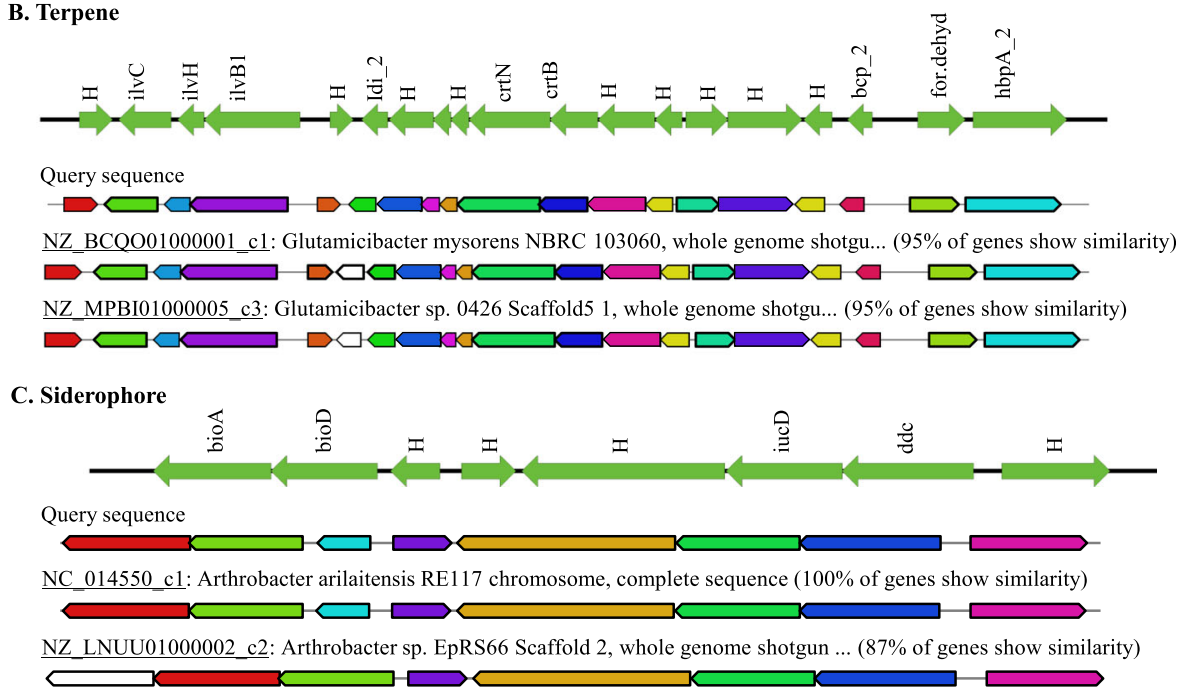

Fig. 5 Identification of biosynthetic gene clusters by antiSMASH v5.0. in G. arilaitensis LJH19 genome. The predicted gene cluster showed a significant hit with other strains of genus Glutamicibacter. H represents the hypothetical gene cluster annotated by prokka v1.14.6. The arrow's direction represents the forward $\left(5^{\prime} \rightarrow 3^{\prime}\right)$ and reverse orientation of the gene cluster 
study, G. arilaitensis LJH19 isolated from NSC demonstrated the ability to hydrolyze complex polysaccharides richly found in night-soil and agricultural residues like starch, cellulose, and xylan. The bacterium survived extreme cold conditions and exhibited several PGP traits such as auxin production, siderophore production, and phosphate solubilization at low ambient temperature. The strain displayed its capabilities as a safe bacterium by demonstrating negative hemolysis and biofilm formation. Genomic search reinforced the bacterium's safety with the absence of any virulence and antibiotic resistance genes. A comprehensive genomic analysis predicted and excavated key genes related to cold adaptation, polysaccharide metabolism, and plant growth promotion. These results indicated G. arilaitensis LJH19 may serve as a safe bioinoculant and may contribute to efficient psychrotrophic bacterial formulations for improved night-soil degradation and soil enrichment PGP attributes. To the best of our knowledge, the current study is the pioneering scientific intervention addressing NSC's issue in the high Himalayas.

\section{Materials and method}

Sampling source, strain isolation, and hydrolytic potential NSC samples were collected from the collection chamber of the night-soil composting toilet, locally termed as 'ghop' of Jundah village $\left(32.64^{\circ} \mathrm{N} 76.84^{\circ} \mathrm{E}\right)$ of Lahaul valley (Fig. 1a). The samples were collected from the core of the compost pile in sterile plastic bottles using stainless steel spatula in triplicates and stored in an icebox containing ice packs. The samples were then immediately transported to the laboratory and processed. The temperature was noted at the time of sampling by inserting the handheld digital thermometer (MEXTECH, India) into the compost pile's core. Air-dried solid sample was mixed with Milli-Q water at a ratio of 1:10 vortexed and kept overnight to check $\mathrm{pH}$ and electrical conductivity (EC) using digital $\mathrm{pH}$ and $\mathrm{EC}$ meter (Eutech, India). The samples were dried at room temperature, finely grounded, and sieved to analyze total available nitrogen, phosphorus, and potassium. All the chemical analysis was performed as per the standard methods for testing compost materials [56].

The bacterial strain LJH19 was isolated from NSC samples while screening for potential psychrotrophic hydrolytic bacteria. The isolation was carried out using serial dilution and spread plate methods on nutrient agar (NA) medium (HiMedia) at $10^{\circ} \mathrm{C}$. The bacterial isolation was performed in Class II, Type A2 Biological Safety Cabinet (Thermo Scientific, US). The optimum growth conditions of the LJH19 strain were determined by incubating the culture at various temperatures $\left(4-50^{\circ} \mathrm{C}\right)$, $\mathrm{NaCl}$ concentration (1-10\%), and $\mathrm{pH}$ (2 to 10$)$ range. The production of hydrolytic enzymes by the LJH19 strain was initially screened using a plate assay method. An exponentially grown culture of LJH19 were spot inoculated on Carboxymethylcellulose (CMC) agar [57], Starch agar (Hi-Media), Xylan agar [58], and Tributyrin agar (Hi-Media) plates and incubated at $10^{\circ} \mathrm{C}$ for $48 \mathrm{~h}$. The clear halo zones around the colony indicated positive results. The enzymatic index (EI=Diameter of the halo of hydrolysis/Diameter of the colony) was calculated as described previously [59]. For quantitative estimation of polysaccharide degrading enzymes viz. cellulase, xylanase, and amylase, the microplate-based 3, 5-dinitrosalicylic acid colorimetry method was followed using $1 \%(\mathrm{w} / \mathrm{v})$ carboxymethylcellulose (CMC), 1\% birchwood xylan (HiMedia), and $1 \%$ soluble starch (HiMedia) as the substrate [60].

\section{Haemolysin and protease assay, biofilm formation and antibiotic susceptibility profile}

For assessment of pathogenic potential, we assayed LJH19 for protease and hemolysin activity using a plate assay method [61]. The strains Staphylococcus aureus subsp. aureus (MTCC 96), Bacillus subtilis (MTCC121), Escherichia coli (MTCC 43), Micrococcus luteus (MTCC 2470) were used as a positive control for hemolytic activity. Hemolytic activity was interpreted according to Buxton [62].

Biofilm formation was evaluated according to Basson and Igbinosa [33, 63] with slight modifications. The adhered cells were stained with $200 \mu \mathrm{L}$ of $0.5 \%$ crystal violet for $10 \mathrm{~min}$. The optical density (OD) readings from respective wells were obtained at $595 \mathrm{~nm}$. The cutoff OD (ODc) for the test was set using the formula (Mean OD of negative control $+3 \mathrm{x}$ Standard deviation), and results were interpreted as previously described [63]. The wells containing only TSB broth $(200 \mu \mathrm{L})$ served as negative control while the wells containing Staphylococcus aureus subsp. aureus (MTCC 96), Bacillus subtilis (MTCC121), Escherichia coli (MTCC 43), Micrococcus luteus (MTCC 2470) were used as a positive control. The test organisms were characterized as non-biofilm producers $(\mathrm{OD}<\mathrm{ODC})$, weak $(\mathrm{ODC}<\mathrm{OD}<2 \mathrm{ODc})$, intermediate (2ODc $<\mathrm{OD}<4 \mathrm{ODc}$ ), and strong (OD $>4 \mathrm{ODc})$.

Antibiotic susceptibility profiling was carried out by using the Kirby-Bauer method [64]. The antibiotic discs (HiMedia) used were $15 \mathrm{mcg}$, Azithromycin (AZM); 10 mcg, Ampicillin (AMP); 5 mcg, Ciprofloxacin (CIP); 30 mcg, Chloramphenicol (CHL); 15 mcg Erythromycin (E); 10 mcg, Gentamycin (G); 30 mcg, Kanamycin (K); 10 Units, Penicillin-G (P); 5 mcg, Rifampicin (RIF); $10 \mathrm{mcg}$, Streptomycin (S); $30 \mathrm{mcg}$, Tetracycline (TE); $30 \mathrm{mcg}$, Vancomycin (VA). The plates were incubated at $10^{\circ} \mathrm{C}$ for $48 \mathrm{~h}$. Zones of clearance were measured in millimetres $(\mathrm{mm})$ and interpreted as Resistant, Intermediate, or Sensitive using the manufacturer's guidelines (HiMedia). 


\section{Plant growth-promoting (PGP) attributes}

Indole acetic acid (IAA) production by LJH19 was studied according to Goswami et al. [65] by supplementing the nutrient broth $(100 \mathrm{ml})$ with L-Trytophan $(200 \mu \mathrm{g}$ $\mathrm{ml}-1)$. The IAA test medium inoculated with strain $\mathrm{LJH} 19$ was incubated at $10^{\circ} \mathrm{C}$, and the colorimetric assay for detection of IAA was performed at room temperature. Siderophore production and phosphate solubilization by LJH19 has initially screened on Chromeazurol S (CAS) agar [66] and Pikovskya's agar (HI Media) at $10^{\circ} \mathrm{C}$. Siderophore producing index (SI) and phosphate solubilization index (PSI) was calculated by dividing zone size by colony diameter.

Quantitative estimation of siderophore was done using CAS-shuttle assay [65] by growing LJH19 in iron-free CAS-broth $\left(\mathrm{pH} \mathrm{6.8)}\right.$ at $10^{\circ} \mathrm{C}$ at $150 \mathrm{rpm}$. To determine siderophore's chemical nature, we examined the absorption maxima ( $\max$ ) of cell-free supernatant in UV-3092 UV/Visible spectrophotometer. Ammonia production was quantified spectrophotometrically [67]. LJH19 was grown in peptone water at $10{ }^{\circ} \mathrm{C}$ for 10 days at $150 \mathrm{rpm}$. Inorganic phosphate solubilization was estimated by the vanado-molybdate method [68] using NBRIP broth containing $0.5 \%$ tricalcium phosphate (TCP).

Seed germination activity of strain LJH19 was carried out using pea seeds (Pisum sativum var. Arkel). The bacterium was grown in nutrient broth for $48 \mathrm{~h}$ at $10^{\circ} \mathrm{C}$ and centrifuged at $10000 \mathrm{rpm}$ to obtain a cell pellet. The pellet was then resuspended in sterile distilled water. Pea seeds were surface sterilized using $5 \%$ sodium hypochlorite for 10 mins, followed by several washes with sterilized distilled water. The surface-sterilized seeds were treated with bacterial suspension for 10 mins and allowed to dry under aseptic conditions. Five seeds per pot were then sown in moist sterile vermiculite. The seeds treated with sterile distilled water with no bacterial inoculant served as the control. The pots were then incubated in a controlled growth chamber with three replicates under mixed incandescent and fluorescent illumination of $550 \mu \mathrm{mol}$ photon $/ \mathrm{m}^{2} / \mathrm{s}$ with a $16 / 8$-h light/dark cycle at $25 \pm 2{ }^{\circ} \mathrm{C}$ and 40 to $50 \%$ relative humidity for 7 days. The number of bacterial cells per seed was approx. $10^{8} \mathrm{CFU}$ determined using serial dilution method [69]. The germination index was then calculated using the equation as described by Mondal et al. [70].

\section{Strain identification, genome sequencing, annotation, phylo-taxono-genomics, and gene content analysis}

The genomic DNA was extracted using the conventional CTAB method [71] and for identification, partial $16 \mathrm{~S}$ rRNA gene sequencing was performed using $27 \mathrm{~F}$ and 1492R primers as described previously [72]. Plasmid DNA isolation was performed using PureLink ${ }^{\circ}$ Quick Plasmid Miniprep Kit (Invitrogen, US).
To provide a genetic basis to the experimental evidence, we performed whole-genome sequencing using PacBio RS-II (Pacific Biosciences, US) as previously $[39,43]$. The draft genome sequence was deposited in NCBI GenBank with accession number SPDS00000000. Strain identification was done at the species level using EzTaxon (https://www.ezbiocloud.net/identify). Manual curation of the genomes from a public repository for the closest match was performed with NCBI Genome (https:// www.ncbi.nlm.nih.gov/genome/?term=Glutamicibacter). Genome quality was assessed using CheckM v1.1.2 [73] in terms of its completeness and contamination present. For the identification of plasmid DNA, in silico analysis was performed using Mash ( $\mathrm{v}$ 2.1.1) distance search against the PLSDB database with the PLSDB web-based tool $(\mathrm{v}$ 0.4.1-6) [74].

Strain phylogeny was assessed using the 16S rRNA gene sequence and whole-genome phylogeny using PhyloPhlAn v0.99 [75]. For the 16S rRNA gene phylogenetic tree construction, all the full-length 16S rRNA reported strains of genus Glutamicibacter were used. Micrococcus luteus (Nucleotide accession No: AF542073) was used as an outgroup. The $16 \mathrm{~S}$ rRNA gene phylogenetic tree was constructed using ClustalX v2.1 [76] and FastTree v2.1.8 [77] with default parameters. Whole-genome phylogeny was constructed using PhyloPhlAN (It uses a 400 most conserved gene across bacterial domains and constructs its phylogeny) (Supplementary Table S1). The assembled scaffolds' functional annotation was performed using the Best-placed reference protein set, GeneMarkS+ version 4.3, with NCBI's Prokaryotic Genome Annotation Pipeline (PGAP) [78]. Additional annotation and the manual review were performed using prokka v1.14.6 [79] and JGI Prokaryotic Automatic Annotation Pipeline [80]. Data mining across the genome of LJH19 was carried out to identify potential genes for endorsement of its potential safe psychrotrophic bio-inoculant candidate as described earlier [32, 38]. The orthoANI v1.2 [81] was performed to infer the taxonomic relatedness of the strain LJH19. ANI value matrix obtained was used for generating heatmap using the webserver of Morpheus (https://software.broadinstitute.org/morpheus). Further, 10 strains forming a clade were considered for pangenome analysis with a 95\% cutoff using Roary v3.6.0 [82]. The unique gene present in the strain LJH19 was fetched and annotated with eggNOG mapper v1 (http:// eggnogdb.embl.de/app/home\#/app/home) [83]. Chromosomal maps for comparing the closely related strains and visualization of the unique genomic region across the strain LJH19 to the type strain RE117 ${ }^{\mathrm{T}}$ and JB182 are marked in the figure (Fig. 3) [84].

To identify the biosynthetic gene clusters (BGCs) in the genome of LJH19, we used a web-based server of antiSMASH v5.0 (https://antismash.secondarymetabolites.org/ 
\#!/start) [85] and a cluster image of the identified biosynthetic gene was prepared with EASYfig v2.2.2 [86]. The putative virulence factors were identified by BLAST against virulence factor database (VFDB) with default parameters (http://www.mgc.ac.cn/VFs/main.htm) [34]. The pathogenic potential of LJH19 was also assessed using the PathogenFinder 1.1 web service under automated mode (https:// cge.cbs.dtu.dk/services/PathogenFinder/) [36]. The presence of antibiotic resistance genes was analyzed using a web-based server of Resistance gene identifier (RGI) v5.1.1 module of Comprehensive Antibiotic Resistance Database (CARD) v3.1.1 by including loose hits (https://card. mcmaster.ca/) [37].

\section{Supplementary Information}

The online version contains supplementary material available at https://doi. org/10.1186/s12864-021-07632-z.

Additional file 1.

\section{Acknowledgements}

SSB is thankful to UGC, Govt. of India for 'Research Fellowship' Grant [UGCRef.No.:461/ (CSIR-UGC NET DEC. 2016)]. RK acknowledges DST, Govt. of India for DST INSPIRE Faculty Award grant number DST/INSPIRE/04/2014/001280, Science and Engineering Research Board Start-up research grant no. SRG/ 2019/001071, and DST-TDT project no. DST/TDT/WM/2019/43. Authors also duly acknowledge the technical support provided by Anil Chaudhary for $16 \mathrm{~S}$ rRNA gene sequencing, Mohit Kumar Swarnkar for whole-genome sequencing, and Dr. Vishal Acharya for genome assembly. The authors also acknowledge Aman Kumar for his technical assistance in figure generation. This manuscript represents CSIR-IHBT communication no. 4602

\section{Authors' contributions}

All authors read and approved the final manuscript. SSB: Performed the experiments, performed analysis, wrote the original draft; AT: Performed the experiments, performed analysis, wrote the original draft; SK: Performed genomic analysis; S K: Performed experiments; RK: Conceptualized the idea, finalized the original draft, supervised the research work; SK: Overall supervision.

\section{Funding}

This work was financially supported by the CSIR in-house projects (MLP 0137, MLP 0143, MLP 0201) and the NMHS project of MoEF\&CC (GBPNI/NMHS2018-19/SG/178).

\section{Availability of data and materials \\ All the data are available in appropriate web portals. 165 rRNA gene sequence data of G. arilaitensis LJH19 is available in NCBI GenBank with accession no. MT349443 (https://www.ncbi.nlm.nih.gov/nuccore/MT349443.1/ ). The whole-genome sequence data of G. arilaitensis LJH19 is available in NCBI GenBank with accession no. SPDS00000000 (https://www.ncbi.nlm.nih. gov/nuccore/SPDS00000000).}

\section{Declarations}

Ethics approval and consent to participate

Ethics approval and consent to participate: Not applicable.

\section{Consent for publication}

Not applicable.

\section{Competing interests}

The authors declare that they have no known competing financial interests or personal relationships that could have appeared to influence the work reported in this paper.

\section{Author details}

${ }^{1}$ Biotechnology Division, CSIR-Institute of Himalayan Bioresource Technology Palampur, Palampur, Himachal Pradesh 176061, India. ${ }^{2}$ Academy of Scientific and Innovative Research (ACSIR), CSIR- Human Resource Development

Centre, Ghaziabad, Uttar Pradesh 201 002, India.

Received: 5 December 2020 Accepted: 20 April 2021

Published online: 28 April 2021

\section{References}

1. Kuniyal JC, Vishvakarma SCR, Singh GS. Changing crop biodiversity and resource use efficiency of traditional versus introduced crops in the cold desert of the northwestern Indian Himalaya: a case of the Lahaul valley. Biodivers Conserv. 2004;13(7):1271-304. https://doi.org/10.1023/B:BIOC. 0000019404.48445 .27$.

2. India science wire. News. In: Scientists intervene to save dry toilets; 2019. Available at: https://vigyanprasar.gov.in/isw/Scientists-intervene-to-save-drytoilets.html (Accessed 3 Dec 2020)

3. Oinam SS, Rawat YS, Kuniyal JC, Vishvakarma SCR, Pandey DC. Thermal supplementing soil nutrients through biocomposting of night-soil in the northwestern Indian Himalaya. Waste Manag. 2008;28(6):1008-19. https:// doi.org/10.1016/j.wasman.2007.03.004.

4. Oinam SS. Traditional night-soil composting continues to bring benefits. Leisa Mag. 2008;24:25-7.

5. Hou N, Wen L, Cao H, Liu K, An X, Li D, et al. Role of psychrotrophic bacteria in organic domestic waste composting in cold regions of China. Bioresour Technol. 2017;236:20-8. https://doi.org/10.1016/j.biortech.2017.03.166.

6. Etesami $H$, Maheshwari DK. Use of plant growth promoting rhizobacteria (PGPRs) with multiple plant growth promoting traits in stress agriculture: action mechanisms and future prospects. Ecotoxicol Environ Saf. 2018;156: 225-46. https://doi.org/10.1016/j.ecoenv.2018.03.013.

7. Numan M, Bashir S, Khan Y, Mumtaz R, Shinwari ZK, Khan AL, et al. Plant growth promoting bacteria as an alternative strategy for salt tolerance in plants: a review. Microbiol Res. 2018;209:21-32. https://doi.org/10.1016/j. micres.2018.02.003.

8. Awasthi MK, Selvam A, Lai KM, Wong JWC. Critical evaluation of postconsumption food waste composting employing thermophilic bacterial consortium. Bioresour Technol. 2017;245(Pt A):665-72. https://doi.org/10.101 6/j.biortech.2017.09.014.

9. Luo Y, Zhou M, Zhao Q, Wang F, Gao J, Sheng H, et al. Complete genome sequence of Sphingomonas sp. Cra20, a drought resistant and plant growth promoting rhizobacteria. Genomics. 2020;112(5):3648-57. https://doi.org/1 0.1016/j.ygeno.2020.04.013.

10. Aarti C, Khusro A, Agastian P. Carboxymethyl cellulase production optimization from Glutamicibacter arilaitensis strain ALA4 and its application in lignocellulosic waste biomass saccharification. Prep Biochem Biotechnol. 2018;48(9):853-66. https://doi.org/10.1080/10826068.2018.1514513.

11. Aarti C, Khusro A, Agastian P. Goat dung as a feedstock for hyperproduction of amylase from Glutamicibacter arilaitensis strain ALA4. Biores Bioprocess. 2017;4(1). https://doi.org/10.1186/s40643-017-0174-4.

12. Santos RG, Hurtado R, Gomes LGR, Profeta R, Rifici C, Attili AR, et al. Complete genome analysis of Glutamicibacter creatinolyticus from mare abscess and comparative genomics provide insight of diversity and adaptation for Glutamicibacter. Gene. 2020;741:144566. https:/doi.org/10.1016/j.gene.2020.144566.

13. Busse HJ. Review of the taxonomy of the genus Arthrobacter, emendation of the genus Arthrobacter sensu lato, proposal to reclassify selected species of the genus Arthrobacter in the novel genera Glutamicibacter gen. Nov., Paeniglutamicibacter gen. nov., Pseudoglutamicibacter gen. nov., Paenarthrobacter gen. nov. and pseudarthrobacter gen. nov., and emended description of Arthrobacter roseus. Int J Syst Evol Microbiol. 2016;66:9-37.

14. Kumar R, Singh D, Swarnkar MK, Singh AK, Kumar S. Complete genome sequence of Arthrobacter alpinus ERGS4:06, a yellow pigmented bacterium tolerant to cold and radiations isolated from Sikkim Himalaya. J Biotechnol. 2016;220:86-7. https://doi.org/10.1016/j.jbiotec.2016.01.016.

15. Singh RN, Gaba S, Yadav AN, Gaur P, Gulati S, Kaushik R, et al. First high quality draft genome sequence of a plant growth promoting and cold active enzyme producing psychrotrophic Arthrobacter agilis strain L77. Stand Genomic Sci. 2016;11(1):54. https://doi.org/10.1186/s40793-016-0176-4.

16. Adesemoye $\mathrm{AO}$, Kloepper JW. Plant-microbes interactions in enhanced fertilizer-use efficiency. Appl Microbiol Biotechnol. 2009;85(1):1-12. https:// doi.org/10.1007/s00253-009-2196-0. 
17. Dey R, Pal KK, Bhatt DM, Chauhan SM. Growth promotion and yield enhancement of peanut (Arachis hypogaea L.) by application of plant growth-promoting rhizobacteria. Microbiol Res. 2004;159(4):371-94. https:// doi.org/10.1016/j.micres.2004.08.004.

18. Iglesias E, Brandariz I, Jiménez C, Soengas RG. Iron(iii) complexation by Vanchrobactin, a siderophore of the bacterial fish pathogen Vibrio anguillarum. Metallomics. 2011;3(5):521-8. https://doi.org/10.1039/ c0mt00071j.

19. Peralta DR, Adler C, Corbalán NS, Paz García EC, Pomares MF, Vincent PA. Enterobactin as part of the oxidative stress response repertoire. PLoS One. 2016;11(6):e0157799. https://doi.org/10.1371/journal.pone.0157799.

20. Gulati A, Vyas P, Rahi P, Kasana RC. Plant growth-promoting and rhizosphere-competent acinetobacter rhizosphaerae strain BIHB 723 from the cold deserts of the himalayas. Curr Microbiol. 2009;58(4):371-7. https:// doi.org/10.1007/s00284-008-9339-x.

21. Rosier A, Medeiros FHV, Bais HP. Defining plant growth promoting rhizobacteria molecular and biochemical networks in beneficial plantmicrobe interactions. Plant Soil. 2018;428(1-2):35-55. https://doi.org/10.1007/ s11104-018-3679-5.

22. You M, Fang S, MacDonald J, Xu J, Yuan ZC. Isolation and characterization of Burkholderia cenocepacia CR318, a phosphate solubilizing bacterium promoting corn growth. Microbiol Res. 2020;233:126395. https://doi.org/10.1 016/j.micres.2019.126395.

23. Karthika S, Midhun SJ, Jisha MS. A potential antifungal and growthpromoting bacterium Bacillus sp. KTMA4 from tomato rhizosphere. Microb Pathog. 2020;142:104049. https://doi.org/10.1016/j.micpath.2020.104049.

24. Zhou S, Zhang $X$, Liao $X$, Wu Y, Mi J, Wang Y. Effect of different proportions of three microbial agents on ammonia mitigation during the composting of layer manure. Molecules. 2019;24(13). https://doi.org/10.3390/ molecules 24132513

25. Qin S, Feng WW, Zhang YJ, Wang TT, Xiong YW, Xing K. Diversity of bacterial microbiota of coastal halophyte Limonium sinense and amelioration of salinity stress damage by symbiotic plant growth-promoting actinobacterium Glutamicibacter halophytocola KLBMP 5180. Appl Environ Microbiol. 2018;84(19):e01533-e01518. https://doi.org/10.1128/A EM.01533-18.

26. Xiong YW, Gong Y, Li XW, Chen P, Ju XY, Zhang CM, et al. Enhancement of growth and salt tolerance of tomato seedlings by a natural halotolerant actinobacterium Glutamicibacter halophytocola KLBMP 5180 isolated from a coastal halophyte. Plant Soil. 2019;445(1-2):307-22. https://doi.org/10.1007/ s11104-019-04310-8

27. Prum C, Dolphen R, Thiravetyan P. Enhancing arsenic removal from arseniccontaminated water by Echinodorus cordifolius-endophytic Arthrobacter creatinolyticus interactions. J Environ Manag. 2018;213:11-9. https://doi. org/10.1016/j.jenvman.2018.02.060.

28. Vavilin VA, Fernandez B, Palatsi J, Flotats X. Hydrolysis kinetics in anaerobic degradation of particulate organic material: An overview. Waste Manag. 2008;28(6):939-51. https://doi.org/10.1016/j.wasman.2007.03.028.

29. See-Too WS, Ee R, Lim YL, Convey P, Pearce DA, Mohidin TBM, et al. Complete genome of Arthrobacter alpinus strain R3.8, bioremediation potential unraveled with genomic analysis. Stand Genomic Sci. 2017;12:1-7.

30. Martínez-García S, Rodríguez-Martínez S, Cancino-Diaz ME, Cancino-Diaz JC. Extracellular proteases of Staphylococcus epidermidis: roles as virulence factors and their participation in biofilm. APMIS. 2018;126(3):177-85. https:// doi.org/10.1111/apm.12805.

31. Wilson BA, Winkler M, Ho BT. Bacterial pathogenesis: a molecular approach. John Wiley \& Sons. 4th edition. Washington, DC:: ASM Press; 2020.

32. Kumar R, Acharya V, Mukhia S, Singh D, Kumar S. Complete genome sequence of Pseudomonas frederiksbergensis ERDD5:01 revealed genetic bases for survivability at high altitude ecosystem and bioprospection potential. Genomics. 2019;111(3):492-9. https://doi.org/10.1016/j.ygeno.2018.03.008.

33. Igbinosa $\mathrm{IH}$, Beshiru A, Odjadjare EE, Ateba CN, Igbinosa EO. Pathogenic potentials of Aeromonas species isolated from aquaculture and abattoir environments. Microb Pathog. 2017;107:185-92. https://doi.org/10.1016/j. micpath.2017.03.037.

34. Liu B, Zheng D, Jin Q, Chen L, Yang J. VFDB 2019: a comparative pathogenomic platform with an interactive web interface. Nucleic Acids Res. 2019;47(D1):D687-92. https://doi.org/10.1093/nar/gky1080.

35. Singh A, Gupta R, Vishwakarma RA, Narayanan PR, Paramasivan CN, Ramanathan VD, et al. Requirement of the mymA operon for appropriate cell wall ultrastructure and persistence of Mycobacterium tuberculosis in the spleens of Guinea pigs. J Bacteriol. 2005;187(12):4173-86. https://doi. org/10.1128/JB.187.12.4173-4186.2005.

36. Cosentino S, Voldby Larsen M, Møller Aarestrup F, Lund O. PathogenFinder distinguishing friend from foe using bacterial whole genome sequence data. PLoS One. 2013;8(12). https://doi.org/10.1371/annotation/b84e1af7-c12 7-45c3-be22-76abd977600f.

37. Alcock BP, Raphenya AR, Lau TTY, Tsang KK, Bouchard M, Edalatmand A, et al. CARD 2020: antibiotic resistome surveillance with the comprehensive antibiotic resistance database. Nucleic Acids Res. 2020;48(D1):D517-25. https://doi.org/10.1093/nar/gkz935.

38. Kumar R, Acharya V, Singh D, Kumar S. Strategies for high-altitude adaptation revealed from high-quality draft genome of non-violacein producing Janthinobacterium lividum ERGS5:01. Stand Genomic Sci. 2018; 13(1):11. https://doi.org/10.1186/s40793-018-0313-3.

39. Swarnkar MK, Singh D, Kumar R. First complete genome sequence of a species in the genus Microterricola, an extremophilic cold active enzyme producing bacterial strain ERGS5:02 isolated from Sikkim Himalaya. J Biotechnol. 2016;222:17-8.

40. Das L, Deb S, Das SK. Glutamicibacter mishrai sp. nov., isolated from the coral Favia veroni from Andaman Sea. Arch Microbiol. 2020;202(4):733-45. https://doi.org/10.1007/s00203-019-01783-0.

41. Monnet C, Loux V, Gibrat JF, Spinnler E, Barbe V, Vacherie B, et al. The Arthrobacter arilaitensis Re117 genome sequence reveals its genetic adaptation to the surface of cheese. PLoS One. 2010;5(11):e15489. https:// doi.org/10.1371/journal.pone.0015489.

42. Nishu SD, Hyun HR, Lee TK. Complete genome sequence of drought tolerant plant growth-promoting rhizobacterium Glutamicibacter halophytocola DR408. Microbiol Soc Korea. 2019;55:300-2.

43. Kumar R, Singh D, Swarnkar MK, Singh AK, Kumar S. Complete genome sequence of Arthrobacter sp. ERGS1:01, a putative novel bacterium with prospective cold active industrial enzymes, isolated from east Rathong glacier in India. J Biotechnol. 2015;214:139-40. https://doi.org/10.1016/j. jbiotec.2015.09.025.

44. Binod P, Gnansounou E, Sindhu R, Pandey A. Enzymes for second generation biofuels: recent developments and future perspectives. Biores Technol Rep. 2019:5:317-25. https://doi.org/10.1016/j.biteb.2018.06.005.

45. Parisutham V, Chandran S-P, Mukhopadhyay A, Lee SK, Keasling JD. Intracellular cellobiose metabolism and its applications in lignocellulosebased biorefineries. Bioresour Technol. 2017;239:496-506. https://doi.org/1 0.1016/j.biortech.2017.05.001

46. Bertoldo C, Antranikian G. Starch-hydrolyzing enzymes from thermophilic archaea and bacteria. Curr Opin Chem Biol. 2002;6(2):151-60. https://doi. org/10.1016/S1367-5931(02)00311-3.

47. Wortham BW, Patel CN, Oliveira MA. Polyamines in bacteria: Pleiotropic effects yet specific mechanisms. Adv Exp Med Biol. 2007;603:106-15.

48. Budzikiewicz H. Mini-reviews in organic chemistry; 2005.

49. Li M, Guo R, Yu F, Chen X, Zhao H, Li H, et al. Indole-3-acetic acid biosynthesis pathways in the plant-beneficial bacterium Arthrobacter pascens ZZ21. Int J Mol Sci. 2018;19(2):443. https://doi.org/10.3390/ijms19020443.

50. Shen W, Yu X, Gao N, Ota S, Shiratori Y, Nishizawa T, et al. Genome sequence of arthrobacter sp. UKPF54-2, a plant growth-promoting rhizobacterial strain isolated from paddy soil. Microbiol Resour Announc. 2019;8:e01005-19.

51. Dinesh R, Srinivasan V, Sheeja TE, Anandaraj M, Srambikkal H. Endophytic actinobacteria: diversity, secondary metabolism and mechanisms to unsilence biosynthetic gene clusters. Crit Rev Microbiol. 2017;43(5):546-66. https://doi.org/10.1080/1040841X.2016.1270895.

52. Shimizu Y, Ogata H, Goto S. Type III Polyketide synthases: functional classification and Phylogenomics. Chembiochem. 2017;18(1):50-65. https:// doi.org/10.1002/cbic.201600522.

53. Liu K, Newman M, McInroy JA, Hu C-H, Kloepper JW. Selection and assessment of plant growth-promoting rhizobacteria for biological control of multiple plant diseases. Phytopathology. 2017;107(8):928-36. https://doi. org/10.1094/PHYTO-02-17-0051-R.

54. Liao L, Su S, Zhao B, Fan C, Zhang J, Li H, et al. Biosynthetic potential of a novel Antarctic Actinobacterium Marisediminicola antarctica ZS314T revealed by genomic data mining and pigment characterization. Marine Drugs. 2019;17(7):388. https://doi.org/10.3390/md17070388.

55. Kumar V, Menon S, Agarwal H, Gopalakrishnan D. Characterization and optimization of bacterium isolated from soil samples for the production of siderophores. Res Technol. 2017:3:434-9. 
56. Baird RB, Chair EW. Rice ADE. Standard Methods for the Examination of Water and Wastewater, 23rd. ed. Water Environment Federation, American Public Health Association, American Water Works Association. 23rd edition. Washington, DC: APHA Press; 2017.

57. Kasana RC, Salwan R, Dhar H, Dutt S, Gulati A. A rapid and easy method for the detection of microbial cellulases on agar plates using Gram's iodine. Curr Microbiol. 2008;57(5):503-7. https://doi.org/10.1007/s00284-008-9276-8.

58. Alves-Prado HF, Pavezzi FC, Leite RSR, De Oliveira VM, Sette LD, DaSilva R. Screening and production study of microbial xylanase producers from Brazilian Cerrado. Appl Biochem Biotechnol. 2010;161(1-8):333-46. https:// doi.org/10.1007/s12010-009-8823-5.

59. Vermelho AB, Couri S. Methods to determine enzymatic activity. Sharjah: Bentham Science Publishers; 2013.

60. Xiao Z, Storms R, Tsang A. Microplate-based carboxymethylcellulose assay for endoglucanase activity. Anal Biochem. 2005;342(1):176-8. https://doi. org/10.1016/j.ab.2005.01.052.

61. Igbinosa $\mathrm{H}$, Chigor VN, Igbinosa EO, Obi LC, Okoh Al. Antibiogram, adhesive characteristics, and incidence of class 1 integron in Aeromonas species isolated from two south African rivers. Biomed Res Int. 2013;2013:1-8. https://doi.org/10.1155/2013/127570.

62. Buxton R. Blood agar plates and hemolysis protocols. Am Soc Microbiol. 2005::1-9. Available at: https://asm.org/getattachment/7ec0de2b-bb16-4f6eba07-2aea25a43e76/protocol-2885.pdf. Accessed 7 Apr 2021

63. Basson A, Flemming LA, Chenia HY. Evaluation of adherence, hydrophobicity, aggregation, and biofilm development of Flavobacterium johnsoniae-like isolates. Microb Ecol. 2008;55(1):1-14. https://doi.org/10.1 007/s00248-007-9245-y.

64. Bauer AT. Antibiotic susceptibility testing by a standardized single disc method. Am J Clin Pathol. 1966;45:149-58.

65. Goswami D, Dhandhukia P, Patel P, Thakker JN. Screening of PGPR from saline desert of Kutch: growth promotion in Arachis hypogea by Bacillus licheniformis A2. Microbiol Res. 2014;169(1):66-75. https://doi.org/10.1016/j. micres.2013.07.004.

66. Lynne AM, Haarmann D, Louden BC. Use of blue agar CAS assay for Siderophore detection. J Microbiol Biol Educ. 2011;12:51-3.

67. Cappuccino JG, Sherman N. New features make the micro lab more clinical application gram staining: the first. Clinical Application (XI). UK: Pearson Education; 2014

68. Gulati A, Sharma N, Vyas P, Sood S, Rahi P, Pathania V, et al. Organic acid production and plant growth promotion as a function of phosphate solubilization by Acinetobacter rhizosphaerae strain BIHB 723 isolated from the cold deserts of the trans-Himalayas. Arch Microbiol. 2010;192(11):975-83. https://doi.org/10.1007/s00203-010-0615-3.

69. Biswas T, Kole SC. Soil organic matter and microbial role in plant productivity and soil fertility; 2017. p. 219-38.

70. Mondal M, Biswas JK, Tsang YF, Sarkar B, Sarkar D, Rai M, et al. A wastewater bacterium Bacillus sp. KUJM2 acts as an agent for remediation of potentially toxic elements and promoter of plant (Lens culinaris) growth. Chemosphere. 2019;232:439-52. https://doi.org/10.1016/j.chemosphere.2 019.05.156.

71. William S, Feil H, Copeland A. Bacterial DNA Isolation CTAB Protocol Bacterial genomic DNA isolation using CTAB Materials \& Reagents. Doe Joint Genome Institute. 2004. p. 4. Available at: http://1 ofdmq2n8tc36m6i4 6scovo2e.wpengine.netdna-cdn.com/wp-content/uploads/2014/02/JGI-Ba cterial-DNA-isolation-CTAB-Protocol-2012.pdf. Accessed 7 Apr 2021.

72. Kumar R, Nongkhlaw M, Acharya C, Joshi SR. Uranium (U)-tolerant bacterial diversity from $U$ ore deposit of Domiasiat in north-East India and its prospective utilisation in bioremediation. Microbes Environ. 2013;28(1):3341. https://doi.org/10.1264/jsme2.ME12074.

73. Parks DH, Imelfort M, Skennerton CT, Hugenholtz P, Tyson GW. CheckM: assessing the quality of microbial genomes recovered from isolates, single cells, and metagenomes. Genome Res. 2015;25(7):1043-55. https://doi.org/1 $0.1101 /$ gr.186072.114.

74. Galata V, Fehlmann T, Backes C, Keller A. PLSDB: a resource of complete bacterial plasmids. Nucleic Acids Res. 2019;47(D1):D195-202.

75. Segata N, Börnigen D, Morgan XC, Huttenhower C. PhyloPhIAn is a new method for improved phylogenetic and taxonomic placement of microbes. Nat Commun. 2013;4(1):2304. https://doi.org/10.1038/ncomms3304.

76. Larkin MA, Blackshields G, Brown NP, Chenna R, McGettigan PA, McWilliam $H$, et al. Clustal W and Clustal X version 2.0. Bioinformatics. 2007;23:2947-8.
77. Price MN, Dehal PS, Arkin AP. FastTree 2-approximately maximumlikelihood trees for large alignments. PLoS One. 2010;5(3):e9490. https://doi. org/10.1371/journal.pone.0009490.

78. Tatusov RL, Galperin MY, Natale DA, Koonin EV. The COG database: a tool for genome-scale analysis of protein functions and evolution. Nucleic Acids Res. 2000;28(1):33-6. https://doi.org/10.1093/nar/28.1.33.

79. Seemann T. Prokka: rapid prokaryotic genome annotation. Bioinformatics. 2014;30(14):2068-9. https://doi.org/10.1093/bioinformatics/btu153.

80. Chen I-MA, Chu K, Palaniappan K, Pillay M, Ratner A, Huang J, et al. IMG/M v. 5.0: an integrated data management and comparative analysis system for microbial genomes and microbiomes. Nucleic Acids Res. 2019;47(D1):D66677. https://doi.org/10.1093/nar/gky901.

81. Yoon SH, Ha S, Lim J, Kwon S, Chun J. A large-scale evaluation of algorithms to calculate average nucleotide identity. Antonie van Leeuwenhoek. Int J Gen Mol Microbiol. 2017;110:1281-6.

82. Page AJ, Cummins CA, Hunt M, Wong VK, Reuter S, Holden MTG, et al. Roary: rapid large-scale prokaryote pan genome analysis. Bioinformatics. 2015;31(22):3691-3. https://doi.org/10.1093/bioinformatics/btv421.

83. Powell S, Forslund K, Szklarczyk D, Trachana K, Roth A, Huerta-Cepas J, et al. eggNOG v4. 0: nested orthology inference across 3686 organisms. Nucleic Acids Res. 2014;42(D1):D231-9. https://doi.org/10.1093/nar/gkt1253.

84. Alikhan NF, Petty NK, Ben Zakour NL, Beatson SA. BLAST ring image generator (BRIG): simple prokaryote genome comparisons. BMC Genomics. 2011;12(1). https://doi.org/10.1186/1471-2164-12-402.

85. Blin K, Shaw S, Steinke K, Villebro R, Ziemert N, Lee SY, et al. AntiSMASH 5.0: updates to the secondary metabolite genome mining pipeline. Nucleic Acids Res. 2019;47(W1):W81-7. https://doi.org/10.1093/nar/gkz310.

86. Sullivan MJ, Petty NK, Beatson SA. Easyfig: A genome comparison visualizer. Bioinformatics. 2011;27(7):1009-10. https://doi.org/10.1093/ bioinformatics/btr039.

\section{Publisher's Note}

Springer Nature remains neutral with regard to jurisdictional claims in published maps and institutional affiliations.

Ready to submit your research? Choose BMC and benefit from:

- fast, convenient online submission

- thorough peer review by experienced researchers in your field

- rapid publication on acceptance

- support for research data, including large and complex data types

- gold Open Access which fosters wider collaboration and increased citations

- maximum visibility for your research: over $100 \mathrm{M}$ website views per year

At BMC, research is always in progress.

Learn more biomedcentral.com/submissions 